\title{
PARP dependent recruitment of RNA methylated at 8-adenosine is linked to base excision repair mechanism
}

\section{Sona Legartova}

Institute of Biophysics of the Czech Academy of Sciences

Jana Suchankova

Institute of Biophysics of the Czech Academy of Sciences

Eva Bartova ( $\square$ bartova@ibp.cz)

Institute of Biophysics of the Czech Academy of Sciences

\section{Research Article}

Keywords: DNA repair, epigenetics, RNA methylation, HRR, NHEJ, NER, BER

Posted Date: September 10th, 2021

DOI: https://doi.org/10.21203/rs.3.rs-892499/v1

License: (c) This work is licensed under a Creative Commons Attribution 4.0 International License.

Read Full License 


\title{
PARP dependent recruitment of RNA methylated at 8-adenosine is linked to base excision repair mechanism
}

\section{Soňa Legartová, Jana Suchánková and Eva Bártová*}

Institute of Biophysics of the Czech Academy of Sciences, Královopolská 135, 612 65, Brno, Czech Republic.

*Correspondence: Eva Bártová, e-mail: bartova@ibp.cz, phone: (+420 5) 41517141. Fax: (+420 5) 41240498.

\begin{abstract}
Methylation of RNAs, especially 6-methyladenosine ( $\left.{ }^{6} \mathrm{~A}\right)$-modified RNAs, plays a specific role in DNA damage response (DDR). Here, we observed that 8-methyladenosine $\left(\mathrm{m}^{8} \mathrm{~A}\right)$-modified RNA is recruited to UVA-microirradiated chromatin, which was reduced by inhibiting both DNA methylation and histone acetylation, especially in later phases of DDR. Most importantly, clinically used PARP inhibitor (PARPi), olaparib, prevents both $\mathrm{m}^{8} \mathrm{~A}$ and $\mathrm{m}^{6} \mathrm{~A}$ RNA accumulation at microirradiated chromatin. Testing the effect of PARPi on the efficiency of BER, NHEJ, and HR repair pathways, we observed that NHEJ repair proteins are down-regulated after PARP inhibition and recruitment of XRCC1, a factor of BER, to DNA lesions was abolished entirely. Conversely, the PARP inhibitor, olaparib, enhanced the genomewide level of $\gamma \mathrm{H} 2 \mathrm{AX}$ that significantly interacted with $\mathrm{m}^{8} \mathrm{~A}$ RNA, similar to DNA. Together, we showed that the recruitment of $\mathrm{m}^{6} \mathrm{~A}$ RNA and $\mathrm{m}^{8} \mathrm{~A}$ RNA to DNA lesions is PARP dependent, similarly as XRCC1 playing a role in the BER mechanism. We found that $\gamma \mathrm{H} 2 \mathrm{AX}$ likely stabilizes $\mathrm{m}^{8} \mathrm{~A} / \mathrm{m}^{6} \mathrm{~A}$ RNA-DNA hybrid loops that are formed during PARP-dependent non-canonical $\mathrm{m}^{6} \mathrm{~A} / \mathrm{m}^{8} \mathrm{~A}$-mediated DNA repair pathway.
\end{abstract}

Keywords: DNA repair; epigenetics; RNA methylation, HRR, NHEJ, NER, BER

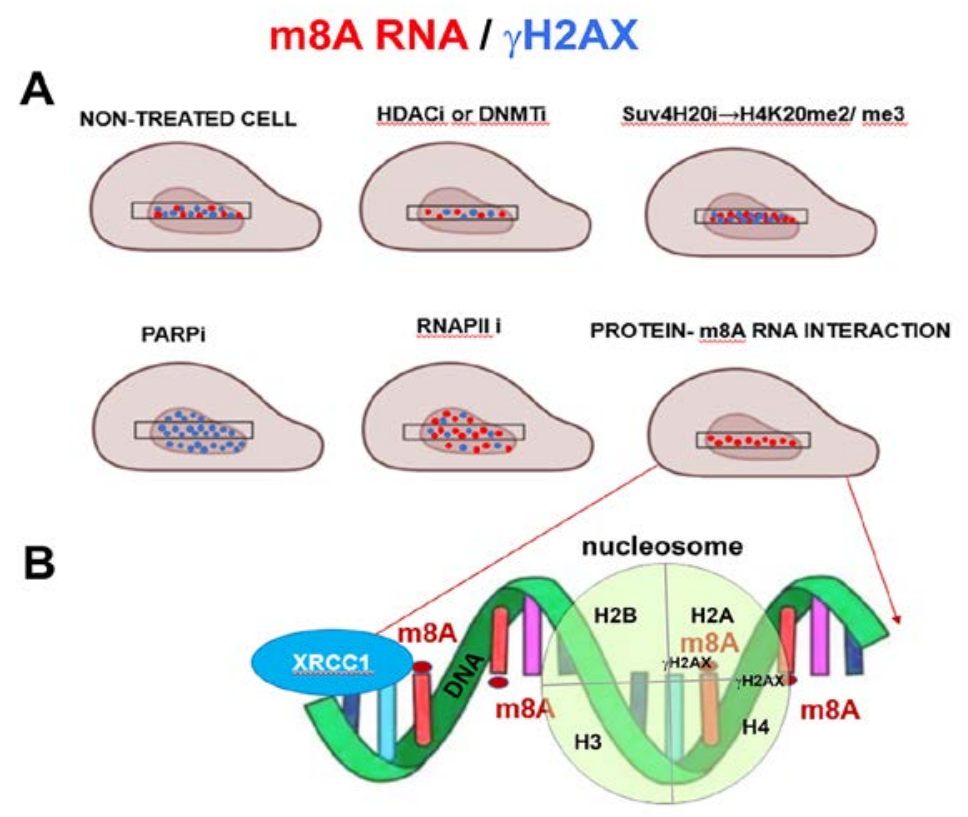


Graphical Abstract: (A) Non-canonical $\mathrm{m}^{6} \mathrm{~A} / \mathrm{m}^{8} \mathrm{~A}$-mediated DNA repair pathway is PARP dependent, and (B) $\gamma \mathrm{H} 2 \mathrm{AX}$ stabilizes $\mathrm{m}^{8} \mathrm{~A} / \mathrm{m}^{6} \mathrm{~A}$ RNA-DNA hybrid loops that are formed as a consequence of genome injury.

\section{Introduction}

Cells developed sophisticated mechanisms for maintaining genome integrity. These mechanisms are called DNA damage response (DDR). Genome injury can be seen as singlestrand breaks in DNA, recognized according to the type of damage by base excision repair mechanism (BER) or nucleotide excision repair (NER) [1]. Very deleterious are the doublestrand breaks (DSBs), which erroneous repair leads to tumorigenesis. To avoid pathological processes caused by non-physiological repair of DSBs, the following two canonical and mechanistically distinct repair pathways are initiated: Non-homologous end joining (NHEJ), active mainly in the G1 phase of the cell cycle and less erroneous homologous recombination repair (HRR), which needs the entry of the cells into the $S$ and G2 phases of the cell cycle [2]. It is well-known that the NHEJ repair mechanism also works in S/G2 phases, but only when the HRR process fails [3]. An essential factor of NHEJ repair machinery is p53-binding protein 1 (53BP1) that forms a barrier inhibiting DNA-end resection, mediated via activation of the specific protein cascade involving Mre11/Rad50/NBS1 complex and replication protein A (RPA). This protein binds to 3' single-stranded DNA (ssDNA) generated by nucleolytic degradation of the 5' strands. Subsequently, Rad51 is recruited to DNA lesions, and Rad51positive nucleoprotein filaments are created. After that, in the later step of HRR, there is BRCA1 that promotes DNA end resection by recruiting the CtIP protein to DNA lesions [4].

DNA repair machinery also has its epigenetic regulations. It is generally accepted that epigenetic adaptations of DNA repair systems involve the function of the phosphorylated form of histone $\mathrm{H} 2 \mathrm{AX}(\gamma \mathrm{H} 2 \mathrm{AX})$. Also, methylation of histone $\mathrm{H} 4$ at lysine 20 position (H4K20me2/me3), as a prominent binding partner of the 53BP1 protein, is a key player at DSB sites [5-9]. Moreover, the disorder in H3K79 and H3K36 methylation was found after exposure of yeast cells to ionizing radiation (IR) [10-13]. In eukaryotic cells, H3K79 methylation, similarly to H4K20 dimethylation, is recognized by the 53BP1 protein $[14,15]$. Also, H3K9me3 represents an epigenetic factor of DDR. An appearance of this epigenetic marker at damaged chromatin is linked to the activation of histone acetyltransferase TIP60, which leads to specific histone acetylation that appears in parallel with phosphorylation of histone H2AX [16-19]. Also, H4K16 acetylation and H2AXK119 ubiquitination appear at DNA lesions, or sirtuin SIRT1 is recruited to I-SceI-induced DSB sites [20]. Similarly, the 
NuRD complex, consisting of HDAC1 and HDAC2, is recruited to damaged chromatin to deacetylate H3K56 [21]. We recently observed the histone deacetylation process in the case of $\mathrm{H} 3 \mathrm{~K} 9$, mediated by histone deacetylase HDAC1 that was recruited to UVA-induced DNA lesions [22].

Recently, it was published that also co-transcriptionally modified RNAs patriciate in DNA damage response. It was shown that there is a novel non-canonical repair pathway mediated via methylated RNA on 6-adenosine $\left(\mathrm{m}^{6} \mathrm{~A}\right)$ [23-25]. This RNA modification is regulated via the function of specific "writes", so call methyl transferases METTL3, METTL14, and METTL16, and recognized by "reader" like the YTHDC1 protein that is additionally associated with specific histone modifications (summarized by [26]). Recently, we additionally showed that mainly METTL16 is recruited to UVA-microirradiated chromatin in later steps of DDR, while the levels of METTL3 and METTL14 proteins remain stable at DSB sites [23]. Xiang et al. (2017) [24] published that methylation at the 6th position of adenosine $\left(\mathrm{m}^{6} \mathrm{~A}\right)$ in RNA appears at DNA lesions immediately after local laser microirradiation, and we documented that this DDR-related event is additionally accompanied by depletion of 2,2,7methylguanosine $\left(\mathrm{m}_{3} \mathrm{G} / \mathrm{TMG}\right)$ in RNA. Significantly, in parallel with described changes in epitranscriptome, UV-irradiation decreases the global cellular level of $\mathrm{N}^{1}$-methyladenosine $\left(\mathrm{m}^{1} \mathrm{~A}\right)$ in RNAs [23]. In this case, mostly when $\mathrm{m}^{6} \mathrm{~A}$ RNAs disappeared at DNA lesions, the level of $\mathrm{m}^{6} \mathrm{~A}$ "eraser", FTO (fat mass and obesity-associated protein; demethylase) remains stable [23]. Above mentioned experimental data documents that the function of $\mathrm{m}^{6} \mathrm{~A}$-specific "writers" and "erasers" is essential for regulating gene expression and physiological DNA damage repair. For instance, it was shown that in the absence of METTL3, there is a delay in repairing UV-induced cyclobutane pyrimidine dimmer (CPDs) and cells are more sensitive to UV light [24,27]. Also, it is well-known that DNA polymerases participate in DNA damage response. For example, DNA polymerase $\kappa(\mathrm{Pol} \kappa)$, playing a role in nucleotide excision repair (NER), works in parallel with the catalytic activity of METTL3 that is recruited to damaged chromatin. Xiang et al. (2017) [24] showed that exogenous overexpression of DNA Pol $\kappa$ rescues the defect of CPDs elimination appearing in METTL-depleted cells. This observation suggests that the fast recruitment of DNA Pol $\kappa$ to the damage site is potentially due to $\mathrm{m}^{6} \mathrm{~A}$ deposition at UV-irradiated genomic regions [27]. Xiang et al. (2017) [24] additionally suggested that METTL3/METTL14 complex (but not METTL3/WTAP complex) in parallel with FTO (but not ALKBH5) serve as the "writers" and the "eraser" of the $\mathrm{m}^{6} \mathrm{~A}$ in RNA accumulating at UV-damaged chromatin. Zhang et al. (2020) [28] showed that ATM-mediated phosphorylation at S43 could activate METTL3, and such phosphorylated protein accumulates 
at DNA lesions, where acts as methyltransferase mediating the $\mathrm{m}^{6} \mathrm{~A}$ in RNA. Also, $\mathrm{m}^{6} \mathrm{~A}$ "reader", the YTHDC1 protein, is recruited to damaged sites [28]. From this view, the existence of a non-canonical $\mathrm{m}^{6} \mathrm{~A}$-mediated pathway, dependent on the PARP [Poly (ADP-ribose) polymerase], was revealed. This newly-described mechanism is specific for UV-irradiated chromatin but not for ionizing-radiation induced foci (IRIF) [24,26,29-34]. Zhang (2017) [34] suggested that this non-canonical DNA repair pathway works independently on phosphorylation of histone $\mathrm{H} 2 \mathrm{AX}$ and is based on the formation of hybrid DNA-RNA loops. It was documented that such DNA-RNA structures appear in the genome as a consequence of DNA damage at transcription sites [35].

Here, we are inspired by the data mentioned above showing novel principles of DNA repair. To continue with the study of the role of RNA modifications in DNA damage response, we addressed whether RNA methylated at 8-adenosine ( $\mathrm{m}^{8} \mathrm{~A}$ RNA) can recognize UV-induced DNA lesions. It is known that this RNA modification is catalyzed by the SAM (S-Adenosyl methionine)-dependent methyltransferase, Cfr [36]. The studies were performed in bacteria, especially in Escherichia coli, in which the Cfr methyltransferase is responsible for the resistance to five different classes of antibiotics. It was described that the Cfr-mediated modification was determined on nucleotide A2503 of 23S rRNA, and also Cfr can catalyze methylation leading to the formation of 2,8-dimethyladenosine. However, the mutation of single conserved cysteine residues in the SAM motif $\mathrm{CxxxCxxC}$ of $\mathrm{Cfr}$ abolishes its activity. Here, we have found $\mathrm{m}^{8} \mathrm{~A}$ RNA positivity at DNA lesions induced in human cells. Notably, the recruitment kinetics of $\mathrm{m}^{8} \mathrm{~A}$ RNA at UV-damaged chromatin was dependent on the PARP function. This observation documents the existence of $\mathrm{m}^{6} \mathrm{~A}$ RNA-and $\mathrm{m}^{8} \mathrm{~A}$ RNA-dependent non-canonical DNA repair pathway.

\section{Materials and methods}

\subsection{Cell cultivation and treatment}

The human cervix adenocarcinoma (HeLa) cell line (ATCC® CCL-2TM, ATCC, UK) was cultivated in EMEM (Eagle's Minimum Essential Medium, Merck, Germany) supplemented with $10 \%$ fetal calf serum (FCS) and the appropriate antibiotics. To study cell cycle-dependent recruitment of proteins to DNA lesions, we used HeLa-FUCCI cells expressing RFP-Cdt1 in the G1 phase and GFP-geminin in the S/G2/M phases have previously been described in detail [37] (Life Technologies; http://www.lifetechnologies.com). HeLa-FUCCI cells were cultivated in 
Dulbecco's modified Eagle's medium supplemented with 10\% FCS and appropriate antibiotics at $37^{\circ} \mathrm{C}$ in a humidified atmosphere containing $5 \% \mathrm{CO}_{2}$.

The HeLa cells were treated with several different inhibitors listed in Table 1 below. This table summarizes used compounds and their final concentration. Also, it contains the time of treatment duration together with a short description of the main inhibition targets.

Table 1. Chemical Compounds used in DNA repair studies

\begin{tabular}{|c|c|c|c|c|}
\hline Compound & Abbreviation & $\begin{array}{l}\text { Final } \\
\text { concentration/ } \\
\text { time }\end{array}$ & $\begin{array}{l}\text { Catalogue } \\
\text { number/ } \\
\text { producer }\end{array}$ & Description \\
\hline A196 & A196i & $\begin{array}{l}5 \mu \mathrm{M} / \\
24 \text { hours }\end{array}$ & $\begin{array}{l}\text { \#SML1565/ } \\
\text { Merck, } \\
\text { Germany }\end{array}$ & $\begin{array}{l}\text { SUV } 420 \mathrm{H} 1 / \mathrm{H} 2 \text { inhibitor } \\
\text { that inhibits the di- and } \\
\text { trimethylation } \\
\text { H4K20me }\end{array}$ \\
\hline Actinomycin D & ActD & $\begin{array}{l}0.5 \mu \mathrm{g} . \mathrm{ml}^{-1} / \\
2 \text { hours }\end{array}$ & $\begin{array}{l}\text { \#A9415/ Merck, } \\
\text { Germany }\end{array}$ & $\begin{array}{l}\text { inhibits mRNA } \\
\text { transcription }\end{array}$ \\
\hline$\alpha$-Amanitin & $\alpha$-Amanitin & $\begin{array}{l}2 \mu \mathrm{g} \cdot \mathrm{ml}^{-1} / \\
2 \text { hours }\end{array}$ & $\begin{array}{l}\text { \#A2263/ Merck, } \\
\text { Germany }\end{array}$ & $\begin{array}{l}\text { inhibits eukaryotic RNA } \\
\text { polymerase II and III, } \\
\text { inhibits mammalian } \\
\text { protein synthesis }\end{array}$ \\
\hline KU-60019 & ATMi & $\begin{array}{l}16 \mu \mathrm{M} / \\
24 \text { hours }\end{array}$ & $\begin{array}{l}\text { \#S1570/ } \\
\text { Selleckchem, } \\
\text { Germany }\end{array}$ & $\begin{array}{l}\text { inhibitor of the ATM } \\
\text { kinase }\end{array}$ \\
\hline $\begin{array}{c}\text { 5-aza-2'- } \\
\text { deoxycytidine }\end{array}$ & 5-AzadC & $\begin{array}{l}10 \mu \mathrm{M} / \\
48 \text { hours }\end{array}$ & $\begin{array}{l}\text { \#A3656/ Merck, } \\
\text { Germany }\end{array}$ & $\begin{array}{ll}\text { inhibits } & \text { DNA } \\
\text { methyltransferase } & \\
\text { activity, causes DNA } \\
\text { demethylation or hemi- } \\
\text { demethylation }\end{array}$ \\
\hline $\begin{array}{l}\text { Suberoylanilide } \\
\text { hydroxamic acid }\end{array}$ & SAHA & $15 \mu \mathrm{M} / 2$ hours & $\begin{array}{l}\text { \#SML0061/ } \\
\text { Merck, } \\
\text { Germany }\end{array}$ & $\begin{array}{l}\text { inhibits class I and class } \\
\text { II HDACs }\end{array}$ \\
\hline Trichostatin A & TSA & $\begin{array}{l}100 \mathrm{nM} / \\
24 \text { hours }\end{array}$ & $\begin{array}{l}\text { \#T8552/ Merck, } \\
\text { Germany }\end{array}$ & $\begin{array}{l}\text { inhibits histone } \\
\text { deacetylase and results in } \\
\text { histone hyperacetylation } \\
\text { that leads to chromatin } \\
\text { relaxation and } \\
\text { modulation of gene } \\
\text { expression }\end{array}$ \\
\hline Olaparib & PARPi & $\begin{array}{l}10 \mu \mathrm{M} / \\
24 \text { hours }\end{array}$ & $\begin{array}{l}\text { \#S1060/ } \\
\text { Selleckchem, } \\
\text { Germany }\end{array}$ & $\begin{array}{l}\text { induces significant } \\
\text { autophagy that is } \\
\text { associated with } \\
\text { mitophagy in cells with } \\
\text { BRCA mutations }\end{array}$ \\
\hline
\end{tabular}

\subsection{Local micro-irradiation of the genome and analysis of DNA lesions with laser scanning confocal microscopy}

For local laser microirradiation, cells were seeded on uncoated, $\gamma$-irradiated, gridded microscope dishes (\#81166, Ibidi, USA). At 50\% confluence, cells were treated with the list of inhibitors see Table 1 and/or pre-sensitized with $10 \mu \mathrm{M}$ 5-Bromo-2'-deoxyuridine (BrdU; 
\#11296736001, Merck, Germany) for 16-18 h (see [38,39]). The cells were irradiated using a TCS SP5-X confocal microscope system (Leica, Germany) equipped with the 355-nm laser and $63 x$ oil objective (HCX PL APO, lambda blue) with a numerical aperture $(\mathrm{NA})=1.4$. The irradiation conditions were optimized according to [24,40,41].

The cells were maintained under optimal cultivation conditions in an incubation chamber (EMBL, Germany) at $37^{\circ} \mathrm{C}$, and the cell culture hood was supplemented with $5 \% \mathrm{CO}_{2}$. Image acquisition for the induction of DSBs was performed with the following settings: 1024 $\times 1024$ pixels, $400 \mathrm{~Hz}$, bidirectional mode, zoom 2. Micro-irradiated cells were monitored for $30 \mathrm{~min}$; immunofluorescence staining was performed at the following intervals (in minutes): $0-5,5-10,10-20,20-30$. After the staining procedure, identical irradiated cells were found on microscope slides using the registered coordinates at gridded microscopic dishes. We quantified the relative fluorescence intensity of either Alexa Fluor 594 dye in HeLa cells or Cy5 dye in HeLa-FUCCI cells, which were used to visualize the proteins accumulations in the regions of interest (ROIs). We used Leica LAS X software to analyze either fluorescence intensity or the number of foci per cell. The statistical analysis was performed using GraphPad Prism 5 software (USA) and the nonparametric Mann-Whitney U test. The asterisks in the Figures represent statistical significance with a p-value $\leq$ of 0.01 . The data are presented as the mean \pm standard error (SE), representing average values from 40 to 60 evaluated cell nuclei per each time point.

\subsection{Immunofluorescence staining}

Immunofluorescence was modified, following [22]. The cells were fixed in 4\% formaldehyde (PFA; \#AAJ19943K2, Fisher Scientific, USA) for $10 \mathrm{~min}$ at room temperature (RT), permeabilized with $0.2 \%$ Triton X-100 (\#194854, MP Biomedicals, USA) for 8 min, and 0.1\% saponin (\#S7900, Merck, Germany) for $13 \mathrm{~min}$. In the next step, the microscopic dishes were washed twice in phosphate buffer saline (PBS) for $15 \mathrm{~min}$. We used 10\% goat serum (\#G9023, Merck, Germany) dissolved in 1x PBS-Triton X-100 (0.1\%) as a blocking solution.

The samples were incubated for one hour at room temperature and then washed in $1 \mathrm{x}$ PBS for $15 \mathrm{~min}$. For immunofluorescence analysis, the following antibodies were used: anti$\mathrm{m}^{8} \mathrm{~A}$ (\#ab211498, Abcam, UK), anti- $\gamma$ H2AX (\#ab2893, Abcam, UK), anti-XRCC1 (\#sc56254, Santa Cruz Biotechnolgy Inc., USA), anti-XPC (\#sc74410, Santa Cruz Biotechnolgy Inc., USA), anti-BRCA1 (\#sc6954, Santa Cruz Biotechnolgy Inc., USA), anti-RAD51 (ab88572, Abcam, UK), anti-MDC1 (\#NBP2-12890, Novus Biological, UK), anti-53BP1 (\#MAB3802, Merck, Germany), anti-53BPpS1778 (\#S2675, Cell Signaling Technology, USA), anti-RIF1 
(\#GTX131889, GeneTex, Taiwan). The indicated primary antibodies were diluted at 1:100 in blocking buffer and incubated at $4{ }^{\circ} \mathrm{C}$ overnight.

The $\mathrm{m}^{6} \mathrm{~A}$ immunostaining was performed following [24]. Briefly, the cells were fixed in $4 \%$ PFA for $10 \mathrm{~min}$ at RT, then permeabilized in $0.25 \%$ Triton X-100 for $30 \mathrm{~min}$. After washing with PBS. As a blocking solution, we used a PBS containing 1\% Bovine Serum Albumin (BSA; \#A2153, Meck, Germany), 10\% Foetal Bovine Serum (FBS; FB-1090/500, BioTech, Czech Republic), and 0.25\% Triton X-100 for 60 min at RT. The primary antibody anti-m ${ }^{6}$ A (\#202003, Synaptic System, Germany) was diluted at 1:100 in blocking buffer and incubated at $4^{\circ} \mathrm{C}$ overnight.

The following secondary antibodies were used: Alexa Fluor 594-conjugated goat antimouse (\#A11032, ThermoFisher Scientific, USA), Alexa Fluor 594-conjugated goat anti-rabbit (\#A11037, ThermoFisher Scientific, USA), and goat anti-rabbit Cy5 (\#ab6564, Abcam, UK).

The secondary antibodies were diluted at 1:200, and incubation time was $60 \mathrm{~min}$ at RT.

For Cyclobutane Pyrimidine Dimers (CPDs) staining, the cells were fixed in 4\% PFA for $10 \mathrm{~min}$ at RT, then permeabilized in $0.5 \%$ Triton $\mathrm{X}-100$ for $5 \mathrm{~min}$ on ice, followed by denaturation with $2 \mathrm{M} \mathrm{HCl}$ for 30 min at RT. After washing with PBS, cells were blocked in a solution containing $20 \% \mathrm{FBS}$ dissolved in $1 \mathrm{x}$ PBS for $60 \mathrm{~min}$ at $37^{\circ} \mathrm{C}$. After the washing step (five times in 1x PBS), cells were incubated with primary antibody anti-CPDs (\#NMDND001, Cosmo Bio Co., Ltd., Japan) for $60 \mathrm{~min}$ at $37^{\circ} \mathrm{C}$. The cells were rewashed twice with 1x PBS and incubated with a secondary antibody Alexa Fluor 594-conjugated goat anti-mouse (\#A11032, ThermoFisher Scientific, USA; dilution 1:100) for 60 minutes at $37^{\circ} \mathrm{C}$.

As negative controls, we incubated samples with antibodies dilution buffers without the primary antibodies. We did not observe signals due to the non-specific binding of secondary antibodies.

A contour of cell nuclei (condensed chromatin) was visualized by the use of 4',6diamidino-2-phenylindole (DAPI; \#D9542, Merck, Germany), dissolved in Vectashield (\#H1000, Vector Laboratories, USA).

We acquired images with Leica TCS SP8X SMD confocal microscope (Leica Microsystem, Germany), equipped with $63 \times$ oil objective (HCX PL APO, lambda blue) with a numerical aperture (NA) 1.4. Image acquisition was performed using a white light laser (WLL; wavelengths of $470-670 \mathrm{~nm}$ in 1-nm increments) with the following parameters: $1024 \times 1024$ 
pixel resolution, $400 \mathrm{~Hz}$, bidirectional mode, and zoom 2. For immunofluorescence analysis, we used Leica Application Suite (LAS X) software, as described above.

\subsection{FLIM-FRET technique}

Fluorescence Lifetime Image (FLIM) Microscopy combined with Förster Resonance Energy Transfer (FRET) was performed following [42]. Using this method, we studied the interactions between XRCC1 protein (donor) and $\mathrm{m}^{8} \mathrm{~A}$ (acceptor), $\gamma \mathrm{H} 2 \mathrm{AX}$ (donor) and $\mathrm{m}^{8} \mathrm{~A}$ (acceptor), and $\mathrm{m}^{8} \mathrm{~A}$ (donor) and DNA (acceptor). The protein-protein interactions were studied at fixed, immunostained samples with the use of the following primary antibodies: anti- $\mathrm{m}^{8} \mathrm{~A}$ (\#ab211498, Abcam, UK), anti-XRCC1 (\#sc56254, Santa Cruz Biotechnolgy Inc., USA), and anti- $\gamma \mathrm{H} 2 \mathrm{AX}$ (\#05-636, Merck, Germany).

As secondary antibodies we used: goat anti-mouse Cy3 (\#ab97035, Abcam, UK), goat anti-rabbit Cy3 (\#A10520, Thermo Fisher Scientific, USA), goat anti-rabbit Cy5 (\#ab6564, Abcam, UK), and TO-PRO-3 Iodide (\#T3506, Thermo Fisher Scientific, USA).

The fluorophores are characterized according to their absorption and fluorescence properties; for example, the higher extinction coefficient (EC) leads to absorbing a more significant amount of light [43]. The specific characteristics of fluorophores used in our FLIMFRET experiments were adopted from the webpage https://www.fpbase.org/fret/ and are summarized in Table 2.

Table 2. Specification of donors and acceptors used for FLIM-FRET experiments

\begin{tabular}{|c|c|c|c|c|c|}
\hline $\begin{array}{l}Y_{\mathrm{Cy3}} \\
\text { (DONOR) }\end{array}$ & $\begin{array}{l}\mathrm{EC}_{\mathrm{Cy} 5} \\
\left(\mathrm{M}^{-1} \mathrm{~cm}^{-1}\right)\end{array}$ & $\begin{array}{l}\text { QY } \\
\text { (ACCEPTOR) }\end{array}$ & $\begin{array}{l}\mathrm{J}(\lambda) \\
\left(* 1 \mathrm{e} 15 \mathrm{M}^{-1} \mathrm{~cm}^{-1} \mathrm{~nm}^{4}\right)\end{array}$ & $\mathbf{R}_{\mathbf{0}}(\mathbf{\AA})$ & $\mathbf{R}_{0} \times \mathbf{Q Y} Y_{C y 5}$ \\
\hline 0.15 & 250000 & 0.30 & 7.6 & 49.73 & 14.92 \\
\hline $\begin{array}{l}\text { QY }_{\text {Cy3 }} \\
\text { (DONOR) }\end{array}$ & $\begin{array}{l}\text { EC }{ }_{\text {TO-PRO-3 }} \\
\left(\mathbf{M}^{-1} \mathbf{c m}^{-1}\right)\end{array}$ & $\begin{array}{l}\text { QY то-PRO-3 } \\
\text { (ACCEPTOR) }\end{array}$ & $\begin{array}{l}\mathrm{J}(\lambda) \\
\left(* 1 \mathrm{e} 15 \mathrm{M}^{-1} \mathrm{~cm}^{-1} \mathrm{~nm}^{4}\right)\end{array}$ & $\mathbf{R}_{0}(\mathbf{\AA})$ & $\mathbf{R}_{0} \times \mathbf{Q Y}_{\mathrm{Cy} 3}$ \\
\hline 0.15 & 150000 & 0.65 & 3.9 & 44.49 & 28.92 \\
\hline
\end{tabular}

$\mathrm{QY}=$ Quantum Yield; $\mathrm{EC}=$ Extinction Coefficient; $\mathrm{J}(\lambda)=$ Overlap Integral, $J(\lambda)=$ $\int_{0}^{\propto} F_{D}(\lambda) \varepsilon_{A}(\lambda) \lambda^{4} d \lambda / \int_{0}^{\propto} F_{D}(\lambda) d \lambda ; \mathrm{R}_{0}=$ Föster Radius, $R_{0}=0.211 \sqrt[6]{\kappa^{2} n^{-4} Q_{D} J(\lambda)} ; \mathrm{n}=$ refractive index and $\kappa^{2}=$ orientation factor $\left.\kappa^{2}=0.6667\right)$.

All samples were mounted in Vectashield (\#H-1000, Vector Laboratories, USA). Measurement was performed using Leica TCS SP8 X SMD confocal microscope (Leica Microsystems GmbH, Germany), PicoHarp 300 module (PicoQuant GmbH, Germany), and HyD SMD detectors. For cell visualization, we used a $63 \times$ oil immersion objective of numerical 
aperture 1.4. We used the pulsed white-light laser (WLL, 470-670 $\mathrm{nm}$ in 1-nm increments) as the excitation source with a repetition rate of $20 \mathrm{MHz}$. We acquired at least 1500 photons/ pixel at the resolution of $512 \times 512$ pixels. Results were analyzed by SymPhoTime 64 software (PicoQuant GmbH, Germany), and FRET efficiency was calculated following $[44,45]$. By the FLIM-FRET technique, we studied up to 40 cell nuclei for each experimental event.

\subsection{Statistical analysis}

For statistical analyses, we used Sigma Plot 14.5 software (Systat Software, Inc., USA). If the data passed the normality test, then the Student's test was applied. If not, the Mann-Whitney Utest was used. The results of the statistical tests were mentioned directly in the figure legend.

\section{Results}

\subsection{The 8-methyladenosine $\left(m^{8} A\right)$-modified $R N A$ is recruited to UVA-microirradiated chromatin}

We addressed whether $\mathrm{m}^{6} \mathrm{~A}$ RNA [22-24] and $\mathrm{m}^{8} \mathrm{~A}$ RNA are recruited to UV-induced DNA lesions. In this case, we have observed that $\mathrm{m}^{8} \mathrm{~A}$ RNAs recognize locally micro-irradiated chromatin immediately after local laser irradiation. However, $\mathrm{m}^{8} \mathrm{~A}$ RNAs positivity weakens 2030 minutes after the UVA-laser cell exposure (Fig. 1Aa, Ba, C). As the next step, we studied if distinct inhibitors of epigenetic processes and DNA repair can change the recruitment properties of $\mathrm{m}^{8} \mathrm{~A}$ RNAs at DNA lesions. We analyzed an effect of Suv20h1/2 inhibitor A196 (A196i) affectioning H4K20me2/me3, a key player of the NHEJ repair mechanism [9,46] (Fig. 1Ab, Bb). Also, we studied the effects of the following compounds: inhibitors of RNA polymerases I and II (Actinomycin D and $\alpha$-amanitin) (Fig. $1 \mathrm{Ac}, \mathrm{Bc}, \mathrm{Ad}, \mathrm{Bd}$ ). Additionally, we performed ATM depletion, which could affect DDR processes (Fig. 1Ae, Be), as well as we studied an effect of inhibition of DNA methyltransferase by 5-aza deoxycytidine (Fig. 1Af, Bf), or inhibition of histone deacetylases (HDACs) by Trichostatin A (TSA) or suberoylanilide hydroxamic acid (Vorinostat; syn. SAHA) (Fig. 1Ag, h and $\mathrm{Bg}, \mathrm{h}$ ). Moreover, we inhibited PARP by olaparib (Fig. 1Ai, Bi). Quantification analyses showed that ATMi, ACT-D, A196i, $\alpha$-amanitin strengthen the accumulation of $\mathrm{m}^{8} \mathrm{~A}$ RNA at locally micro-irradiated chromatin (Fig. 1C, D), while HDAC inhibitors, TSA, and SAHA (inducing hyperacetylation) reduced the level of $\mathrm{m}^{8} \mathrm{~A}$ RNAs at locally-induced DNA lesions (Fig. 1C, D). Importantly, PARP inhibitor olaparib completely abrogated $\mathrm{m}^{8} \mathrm{~A}$ RNA recruitment to DNA lesions (Fig. 1Ai, Bi and Fig. 1C, D). Recruitment kinetics of $\mathrm{m}^{8} \mathrm{~A}$ RNA to DNA lesions also changed over time. The most pronounced accumulation was 0-5 min after micro-irradiation. The significantly reduced $\mathrm{m}^{8} \mathrm{~A}$ RNA signal at 
DNA lesion was 15-30 min post-irradiation, especially when the cells were treated by 5-AzaC, TSA, or SAHA (Fig. 1C).

To the above-mentioned phenomenon, we additionally observed that the recruitment of $\mathrm{m}^{8} \mathrm{~A}$ RNA to DNA lesions is stable during the interphase of the cell cycle. It is documented in HeLa cells stably expressing the so-called FUCCI system, according to which it is possible to recognize cells in the G1 phase, expressing RFP-tagged cdt1, and G2 phase-cells expressing GFP-tagged geminin. S-phase can be identified according to the weak expression of both markers see Fig. 2A. Quantification of $\mathrm{m}^{8} \mathrm{~A}$ RNA density in irradiated chromatin of FUCCI cells, see in Fig. 1B. Similarly, $\mathrm{m}^{6}$ A RNA recognized locally-induced DNA lesions in all cell cycle phases (Fig. 2C, D).

In parallel with $\mathrm{m}^{8} \mathrm{~A}$ RNA at locally-induced DNA lesions (Fig. 2), we have studied the kinetics of $\mathrm{m}^{6} \mathrm{~A}$ RNA at DSB sites of PARPi treated cells. We have observed similar results for $\mathrm{m}^{6} \mathrm{~A}$ RNA as for $\mathrm{m}^{8} \mathrm{~A}$ RNA, meaning that PARP inhibitor olaparib abolished recruitment of $\mathrm{m}^{6} \mathrm{~A}$ RNA to locally-induced DNA lesions (Fig. 3).

\subsection{PARP inhibitor increased $\gamma H 2 A X$ positivity in the whole cell nuclei, did not change the} level of CPDs at locally induced DNA lesions and abolished recruitment of XRCC1 to microirradiated genomic regions.

We found that PARP inhibitor, olaparib, has no potential to change the levels of XPC and CPDs (factors of nucleotide excision repair mechanism, NER) at DNA lesions. In contrast, olaparib potentiates $\gamma \mathrm{H} 2 \mathrm{AX}$ positivity in the whole cell nuclei (Fig. 4A, Ba, c, d). Importantly, PARPi prevents accumulation of $\mathrm{XRCC} 1$, a factor of base excision repair, BER, to UVA-damaged chromatin (Fig. 34, Bb). Importantly, PARPi causes an increase of $\gamma \mathrm{H} 2 \mathrm{AX}$ positive foci per cell, while did not change the number of XRCC1 positive foci (Fig. 4C, D).

\subsection{PARP inhibitor reduced the level of the 53BP1 protein, 53BP1pS1778 and RIF1 in} microirradiated chromatin, while the level of HRR-related proteins was relatively stable

Due to the fact that PARP inhibitor olaparib abrogated recruitment of $\mathrm{m}^{8} \mathrm{~A}$ RNA at DNA lesions, we have analyzed how PARPi affects factors of homologous recombination repair (HRR) and non-homologous end joining (NHEJ) repair mechanism. We have observed that factors of HRR were stable after PARP inhibition at locally-induced DNA lesions. This trend was observed in many post-irradiation intervals (Fig. 5Aa-c, Ba-c). An exception was up-regulation of the MDC1 protein in the later step of DDR; 20-30 after microirradiation (Fig. 5Ac, Bc). Interestingly, the number of DNA repair foci induced by microirradiation was significantly increased by olaparib 
treatment when we studied MDC1-positivity (Fig. 5Cc). However, BRCA1- and RAD51positive foci were not changed when the cells were treated with olaparib (Fig. 5Ca, b).

Besides HRR factors, we have studied proteins involved in the HNEJ repair pathway. We analyzed recruitment kinetics to microirradiated chromatin for 53BP1, its phosphorylated form, 53BP1pS1778, and the RIF1 protein. We observed protein down-regulation at DNA lesions in all cases studied when the cells were treated by PARPi (Fig. 6Aa-c, Ba-c). Notably, the number of DNA repair foci after microirradiation was not changed by olaparib treatment (Fig. 6Ca-c).

\section{4. $m^{8} A R N A$ interacts identically with $D N A$ and $\gamma H 2 A X$}

Using FLIM-FRET analysis, we studied a degree of interaction between m8A RNA and XRCC1, a protein that, similarly to $\mathrm{m}^{8} \mathrm{~A}$ RNA, was recruited to DNA lesions in normal cells. Still, the treatment by PARP inhibitor abolished the accumulation of both $\mathrm{m}^{8} \mathrm{~A}$ RNA and XRCC1 at microirradiated chromatin (Fig. 1Ai, 4A, Bb). In this case, we have observed the interaction properties on the so-called cut-off level that we established at $20 \%$ when measuring FLIM- FRET efficiency [47] (Fig. 7a). However, a significant FLIM-FRET efficiency was observed when we measured $\mathrm{m}^{8} \mathrm{~A}$ RNA interaction with $\gamma \mathrm{H} 2 \mathrm{AX}$ or $\mathrm{m}^{8} \mathrm{~A}$ RNA binding to DNA. In these cases, FLIM-FRET efficiency was approximately $30 \%$. Interestingly, UVA-local microirradiation did not change the interaction properties of studied partners (Fig. 7b, c). Due to high FLIM-FRET efficiency for $\mathrm{m}^{8} \mathrm{~A}$ RNA and DNA, these data support the existence of $\mathrm{m}^{8} \mathrm{~A}$ RNA-DNA hybrids that stabilize the genome after injury in the form of R-loops. Based on our FLIM-FRET data, it seems likely that also $\gamma \mathrm{H} 2 \mathrm{AX}$ contributes to this process (see high FLIM-FRET efficiency in Fig. $7 b)$.

\section{Discussion}

Yu et al. (2021) [48] showed that the function of the METTL3-METTL14 complex, similarly to $\mathrm{m}^{6} \mathrm{~A}$ RNA nuclear reader YTHDC1, contributes to the repair of DNA lesions containing cyclobutene pyrimidine dimers, which are well-characterized elements that appear after UVirradiation. Moreover, N6-methyladenine (N6mA) reduced misincorporation of 8-oxo-guanine (8-oxoG) opposite to N6mA by repair DNA polymerases. When 8-oxoG is incorporated into the opposite site to N6mA, this process inhibits N6mA excision from the template [48]. From this observation, it is evident that METTL3/METTL14 methyltransferases, together with $\mathrm{m}^{6} \mathrm{~A}$ RNAs, are required for DNA damage repair mechanisms that are initiated by UV radiation [23,24]. From this view, Zhang et al. (2017) [49] suggested the existence of a non-canonical $\mathrm{m}^{6} \mathrm{~A}$-mediated, PARP-dependent DNA repair pathway recognizing UV-induced DNA lesions. The same we 
have observed for $\mathrm{m}^{8} \mathrm{~A}$ RNAs, which appeared at DNA lesions in a PARP-dependent way, because PARP inhibitor, olaparib, completely prevents recruitment of $\mathrm{m}^{8} \mathrm{~A}$ RNAs to locallyirradiated chromatin (Fig. 1Ai, Bi, C, D). Also, hyperacetylation, induced by HDAC inhibitors, significantly reduced $\mathrm{m}^{8} \mathrm{~A}$ RNA recruitment to microirradiated chromatin (Fig. $1 \mathrm{Ag}, \mathrm{h}$ and $\mathrm{Bg}$, h, C, D).

A fundamental observation of hybrid DNA-RNA loops in which $\mathrm{m}^{6} \mathrm{~A}$ on RNA strand contributes to genome stability. Critical $\mathrm{m}^{6} \mathrm{~A}$ readers like YTHDF2 or YTHDC1 recognize $\mathrm{m}^{6} \mathrm{~A}$ on R-loops, and this DDR-related event contributes to the efficiency of DNA repair. Moreover, it was documented that RNAse $\mathrm{H} 1$ function plays a role in this process, which is essential for genome stability [35]. Ohle et al. (2016) [31], Costantino and Koshland (2018) [29], Lu et al. (2018) [50], García-Muse and Aguilera (2019) [30], Jimeno et al. (2019) [26], Paull (2019) [32], Puget et al. (2019) [33] or Domingo-Prim et al. (2020) [51] showed that R-loops at the sites of the break act in both positive and negative way in HRR. Interestingly, R-loops in the vicinity to DSB sites can recruit factors of HRR, including Rad52 and BRCA1, in turn counteracting the anti-resection activity of the Shieldin complex, consisting of C20orf196 (also known as SHLD1), FAM35A (SHLD2), CTC-534A2.2 (SHLD3) and REV7 proteins recognizing DSB sites and working in 53BP1- and RIF1-dependent pathway of NHEJ [52]. From our experiments, it seems evident that the formation of $\mathrm{m}^{6} \mathrm{~A}$ RNA- and $\mathrm{m}^{8} \mathrm{~A}$ RNA-DNA loops are likely essential for UVinduced DNA repair processes. In our case, these hybrid loops are rather involved in a BER mechanism because the protein of BER, XRCC1, works identically as $\mathrm{m}^{8} \mathrm{~A}$ RNA after inhibition of PARP (Fig. 1Ai, 4A, Bc). Also, it must be considered that the formation of hybrid RNA-DNA loops needs end-resection in S-phase. Thus, it can proceed in the S/G2 phases of the cell cycle, but we have also observed both $\mathrm{m}^{8} \mathrm{~A}$ RNAs and $\mathrm{m}^{6} \mathrm{~A}$ RNAs accumulated at DNA lesions induced in the G1 cells (Fig. 2A-D). So, our results imply that $\mathrm{m}^{8} \mathrm{~A}$ RNAs contribute to the BER repair mechanism; moreover, as shown by FLIM-FRET analysis, $\gamma \mathrm{H} 2 \mathrm{AX}$ likely stabilizes $\mathrm{m}^{8} \mathrm{~A}$ RNADNA loop formation after genome injury, and this process is PARP dependent.

\section{Authors' contribution}

$\mathrm{SL}$ is responsible for all experimental results and has written the methodology section. EB suggested all experiments, coordinated practical progress, finalized all images and wrote this paper. 


\section{Funding}

This work was supported by the Internal support of the Institute of Biophysics of the Czech Academy of Sciences (68081707) and by Strategie AV21, supported by the Czech Academy of Sciences.

\section{Acknowledgement}

We want to thank Dr. Jana Suchánková for optimizing and improving the protocol for local micro-irradiation experiments.

\section{Conflict of interest statement}

The authors have declared that there are no conflicts of interest.

\section{References}

1. Chatterjee, N.; Walker, G.C. Mechanisms of DNA damage, repair, and mutagenesis. Environ Mol Mutagen 2017, 58, 235-263, doi:10.1002/em.22087.

2. Mao, Z.; Bozzella, M.; Seluanov, A.; Gorbunova, V. Comparison of non-homologous end joining and homologous recombination in human cells. DNA Repair (Amst) 2008, 7, 1765-1771, doi:10.1016/j.dnarep.2008.06.018.

3. Shrivastav, M.; De Haro, L.P.; Nickoloff, J.A. Regulation of DNA double-strand break repair pathway choice. Cell Res 2008, 18, 134-147, doi:10.1038/cr.2007.111.

4. Li, X.; Heyer, W.D. Homologous recombination in DNA repair and DNA damage tolerance. Cell Res 2008, 18, 99-113, doi:10.1038/cr.2008.1.

5. Ataian, Y.; Krebs, J.E. Five repair pathways in one context: chromatin modification during DNA repair. Biochem Cell Biol 2006, 84, 490-504, doi:10.1139/o06-075.

6. Bao, Y. Chromatin response to DNA double-strand break damage. Epigenomics 2011, 3, 307-321, doi:10.2217/epi.11.14.

7. Downs, J.A.; Allard, S.; Jobin-Robitaille, O.; Javaheri, A.; Auger, A.; Bouchard, N.; Kron, S.J.; Jackson, S.P.; Cote, J. Binding of chromatin-modifying activities to phosphorylated histone H2A at DNA damage sites. Mol Cell 2004, 16, 979-990, doi:10.1016/j.molcel.2004.12.003.

8. Rogakou, E.P.; Pilch, D.R.; Orr, A.H.; Ivanova, V.S.; Bonner, W.M. DNA doublestranded breaks induce histone $\mathrm{H} 2 \mathrm{AX}$ phosphorylation on serine 139. J Biol Chem 1998, 273, 5858-5868, doi:10.1074/jbc.273.10.5858.

9. Svobodova Kovarikova, A.; Legartova, S.; Krejci, J.; Bartova, E. H3K9me3 and H4K20me3 represent the epigenetic landscape for 53BP1 binding to DNA lesions. Aging (Albany NY) 2018, 10, 2585-2605, doi:10.18632/aging.101572.

10. Game, J.C.; Chernikova, S.B. The role of RAD6 in recombinational repair, checkpoints and meiosis via histone modification. DNA Repair (Amst) 2009, 8, 470-482, doi:10.1016/j.dnarep.2009.01.007.

11. Game, J.C.; Williamson, M.S.; Baccari, C. X-ray survival characteristics and genetic analysis for nine Saccharomyces deletion mutants that show altered radiation sensitivity. Genetics 2005, 169, 51-63, doi:10.1534/genetics.104.028613.

12. Game, J.C.; Williamson, M.S.; Spicakova, T.; Brown, J.M. The RAD6/BRE1 histone modification pathway in Saccharomyces confers radiation resistance through a RAD51- 
dependent process that is independent of RAD18. Genetics 2006, 173, 1951-1968, doi:10.1534/genetics.106.057794.

13. Grenon, M.; Costelloe, T.; Jimeno, S.; O'Shaughnessy, A.; Fitzgerald, J.; Zgheib, O.; Degerth, L.; Lowndes, N.F. Docking onto chromatin via the Saccharomyces cerevisiae Rad9 Tudor domain. Yeast 2007, 24, 105-119, doi:10.1002/yea.1441.

14. Hartlerode, A.J.; Guan, Y.; Rajendran, A.; Ura, K.; Schotta, G.; Xie, A.; Shah, J.V.; Scully, R. Impact of histone H4 lysine 20 methylation on 53BP1 responses to chromosomal double strand breaks. PLoS One 2012, 7, e49211, doi:10.1371/journal.pone.0049211.

15. Hsiao, K.Y.; Mizzen, C.A. Histone H4 deacetylation facilitates 53BP1 DNA damage signaling and double-strand break repair. J Mol Cell Biol 2013, 5, 157-165, doi:10.1093/jmcb/mjs066.

16. Ikura, T.; Ogryzko, V.V.; Grigoriev, M.; Groisman, R.; Wang, J.; Horikoshi, M.; Scully, R.; Qin, J.; Nakatani, Y. Involvement of the TIP60 histone acetylase complex in DNA repair and apoptosis. Cell 2000, 102, 463-473, doi:10.1016/s0092-8674(00)00051-9.

17. Murr, R.; Loizou, J.I.; Yang, Y.G.; Cuenin, C.; Li, H.; Wang, Z.Q.; Herceg, Z. Histone acetylation by Trrap-Tip60 modulates loading of repair proteins and repair of DNA double-strand breaks. Nat Cell Biol 2006, 8, 91-99, doi:10.1038/ncb1343.

18. $\mathrm{Xu}, \mathrm{Y}$.; Price, B.D. Chromatin dynamics and the repair of DNA double strand breaks. Cell Cycle 2011, 10, 261-267, doi:10.4161/cc.10.2.14543.

19. Xu, Y.; Sun, Y.; Jiang, X.; Ayrapetov, M.K.; Moskwa, P.; Yang, S.; Weinstock, D.M.; Price, B.D. The p400 ATPase regulates nucleosome stability and chromatin ubiquitination during DNA repair. $J$ Cell Biol 2010, 191, 31-43, doi:10.1083/jcb.201001160.

20. Dobbin, M.M.; Madabhushi, R.; Pan, L.; Chen, Y.; Kim, D.; Gao, J.; Ahanonu, B.; Pao, P.C.; Qiu, Y.; Zhao, Y., et al. SIRT1 collaborates with ATM and HDAC1 to maintain genomic stability in neurons. Nat Neurosci 2013, 16, 1008-1015, doi:10.1038/nn.3460.

21. Miller, K.M.; Tjeertes, J.V.; Coates, J.; Legube, G.; Polo, S.E.; Britton, S.; Jackson, S.P. Human HDAC1 and HDAC2 function in the DNA-damage response to promote DNA non-homologous end-joining. Nat Struct Mol Biol 2010, 17, 1144-1151, doi:10.1038/nsmb.1899.

22. Bartova, E.; Sustackova, G.; Stixova, L.; Kozubek, S.; Legartova, S.; Foltankova, V. Recruitment of Oct4 protein to UV-damaged chromatin in embryonic stem cells. PLoS One 2011, 6, e27281, doi:10.1371/journal.pone.0027281.

23. Svobodova Kovarikova, A.; Stixova, L.; Kovarik, A.; Komurkova, D.; Legartova, S.; Fagherazzi, P.; Bartova, E. N(6)-Adenosine Methylation in RNA and a Reduced m3G/TMG Level in Non-Coding RNAs Appear at Microirradiation-Induced DNA Lesions. Cells 2020, 9, doi:10.3390/cells9020360.

24. Xiang, Y.; Laurent, B.; Hsu, C.H.; Nachtergaele, S.; Lu, Z.; Sheng, W.; Xu, C.; Chen, H.; Ouyang, J.; Wang, S., et al. RNA m(6)A methylation regulates the ultravioletinduced DNA damage response. Nature 2017, 543, 573-576, doi:10.1038/nature21671.

25. Zhang, S.; Zhao, B.S.; Zhou, A.; Lin, K.; Zheng, S.; Lu, Z.; Chen, Y.; Sulman, E.P.; Xie, K.; Bogler, O., et al. m(6)A Demethylase ALKBH5 Maintains Tumorigenicity of Glioblastoma Stem-like Cells by Sustaining FOXM1 Expression and Cell Proliferation Program. Cancer Cell 2017, 31, 591-606 e596, doi:10.1016/j.ccell.2017.02.013.

26. Jimeno, S.; Balestra, F.R.; Huertas, P. The Emerging Role of RNA Modifications in DNA Double-Strand Break Repair. Front Mol Biosci 2021, 8, 664872, doi:10.3389/fmolb.2021.664872. 
27. Zhang, M.; Wang, L.; Zhong, D. Photolyase: Dynamics and Mechanisms of Repair of Sun-Induced DNA Damage. Photochem Photobiol 2017, 93, 78-92, doi:10.1111/php.12695.

28. Zhang, C.; Chen, L.; Peng, D.; Jiang, A.; He, Y.; Zeng, Y.; Xie, C.; Zhou, H.; Luo, X.; Liu, H., et al. METTL3 and N6-Methyladenosine Promote Homologous Recombination-Mediated Repair of DSBs by Modulating DNA-RNA Hybrid Accumulation. Mol Cell 2020, 79, 425-442 e427, doi:10.1016/j.molcel.2020.06.017.

29. Costantino, L.; Koshland, D. Genome-wide Map of R-Loop-Induced Damage Reveals How a Subset of R-Loops Contributes to Genomic Instability. Mol Cell 2018, 71, 487497 e483, doi:10.1016/j.molcel.2018.06.037.

30. Garcia-Muse, T.; Aguilera, A. R Loops: From Physiological to Pathological Roles. Cell 2019, 179, 604-618, doi:10.1016/j.cell.2019.08.055.

31. Ohle, C.; Tesorero, R.; Schermann, G.; Dobrev, N.; Sinning, I.; Fischer, T. Transient RNA-DNA Hybrids Are Required for Efficient Double-Strand Break Repair. Cell 2016, 167, 1001-1013 e1007, doi:10.1016/j.cell.2016.10.001.

32. Paull, T.T. RNA-DNA hybrids and the convergence with DNA repair. Crit Rev Biochem Mol Biol 2019, 54, 371-384, doi:10.1080/10409238.2019.1670131.

33. Puget, N.; Miller, K.M.; Legube, G. Non-canonical DNA/RNA structures during Transcription-Coupled Double-Strand Break Repair: Roadblocks or Bona fide repair intermediates? DNA Repair (Amst) 2019, 81, 102661, doi:10.1016/j.dnarep.2019.102661.

34. Zhang, A.; Peng, B.; Huang, P.; Chen, J.; Gong, Z. The p53-binding protein 1-Tudorinteracting repair regulator complex participates in the DNA damage response. $J$ Biol Chem 2017, 292, 6461-6467, doi:10.1074/jbc.M117.777474.

35. Qu, F.; Tsegay, P.S.; Liu, Y. N(6)-Methyladenosine, DNA Repair, and Genome Stability. Front Mol Biosci 2021, 8, 645823, doi:10.3389/fmolb.2021.645823.

36. Giessing, A.M.; Jensen, S.S.; Rasmussen, A.; Hansen, L.H.; Gondela, A.; Long, K.; Vester, B.; Kirpekar, F. Identification of 8-methyladenosine as the modification catalyzed by the radical SAM methyltransferase Cfr that confers antibiotic resistance in bacteria. RNA 2009, 15, 327-336, doi:10.1261/rna.1371409.

37. Sakaue-Sawano, A.; Ohtawa, K.; Hama, H.; Kawano, M.; Ogawa, M.; Miyawaki, A. Tracing the silhouette of individual cells in S/G2/M phases with fluorescence. Chem Biol 2008, 15, 1243-1248, doi:10.1016/j.chembiol.2008.10.015.

38. Luijsterburg, M.S.; Dinant, C.; Lans, H.; Stap, J.; Wiernasz, E.; Lagerwerf, S.; Warmerdam, D.O.; Lindh, M.; Brink, M.C.; Dobrucki, J.W., et al. Heterochromatin protein 1 is recruited to various types of DNA damage. J Cell Biol 2009, 185, 577-586, doi:10.1083/jcb.200810035.

39. Sustackova, G.; Kozubek, S.; Stixova, L.; Legartova, S.; Matula, P.; Orlova, D.; Bartova, E. Acetylation-dependent nuclear arrangement and recruitment of BMI1 protein to UV-damaged chromatin. $J$ Cell Physiol 2012, 227, 1838-1850, doi:10.1002/jcp.22912.

40. Jawad, M.M.; Qader, S.T.A.; Zaidan, A.A.; Zaidan, B.B.; Naji, A.W.; Qader, I.T.A. An Overview of Laser Principle, Laser-Tissue Interaction Mechanisms and Laser Safety Precautions for Medical Laser Users. Int $J$ Pharmacol 2011, 7, 149-160, doi:10.3923/ijp.2011.149.160.

41. Suchankova, J.; Legartova, S.; Ruckova, E.; Vojtesek, B.; Kozubek, S.; Bartova, E. Mutations in the TP53 gene affected recruitment of 53BP1 protein to DNA lesions, but level of 53BP1 was stable after gamma-irradiation that depleted MDC1 protein in specific TP53 mutants. Histochem Cell Biol 2017, 148, 239-255, doi:10.1007/s00418017-1567-3. 
42. Legartova, S.; Lochmanova, G.; Zdrahal, Z.; Kozubek, S.; Sponer, J.; Krepl, M.; Pokorna, P.; Bartova, E. DNA Damage Changes Distribution Pattern and Levels of HP1 Protein Isoforms in the Nucleolus and Increases Phosphorylation of HP1beta-Ser88. Cells 2019, 8, doi:10.3390/cells8091097.

43. Kumar, S.; Alibhai, D.; Margineanu, A.; Laine, R.; Kennedy, G.; McGinty, J.; Warren, S.; Kelly, D.; Alexandrov, Y.; Munro, I., et al. FLIM FRET technology for drug discovery: automated multiwell-plate high-content analysis, multiplexed readouts and application in situ. Chemphyschem 2011, 12, 609-626, doi:10.1002/cphc.201000874.

44. Lakowicz, J.R.; Gryczynski, I.I.; Gryczynski, Z. High Throughput Screening with Multiphoton Excitation. $J$ Biomol Screen 1999, 4, 355-362, doi:10.1177/108705719900400610.

45. Sillen, A.; Engelborghs, Y. The correct use of "average" fluorescence parameters. Photochem Photobiol 1998, 67, 475-486, doi:DOI 10.1111/j.17511097.1998.tb09443.x.

46. Paquin, K.L.; Howlett, N.G. Understanding the Histone DNA Repair Code: H4K20me2 Makes Its Mark. Mol Cancer Res 2018, 16, 1335-1345, doi:10.1158/1541-7786.MCR17-0688.

47. Sehnalova, P.; Legartova, S.; Cmarko, D.; Kozubek, S.; Bartova, E. Recruitment of HP1beta to UVA-induced DNA lesions is independent of radiation-induced changes in A-type lamins. Biol Cell 2014, 106, 151-165, doi:10.1111/boc.201300076.

48. Yu, D.; Horton, J.R.; Yang, J.; Hajian, T.; Vedadi, M.; Sagum, C.A.; Bedford, M.T.; Blumenthal, R.M.; Zhang, X.; Cheng, X. Human MettL3-MettL14 RNA adenine methyltransferase complex is active on double-stranded DNA containing lesions. Nucleic Acids Res 2021, 10.1093/nar/gkab460, doi:10.1093/nar/gkab460.

49. Zhang, J. Brothers in arms: emerging roles of RNA epigenetics in DNA damage repair. Cell Biosci 2017, 7, 24, doi:10.1186/s13578-017-0151-9.

50. Lu, S.; Dong, W.; Zhao, P.; Liu, Z. IncRNA FAM83H-AS1 is associated with the prognosis of colorectal carcinoma and promotes cell proliferation by targeting the Notch signaling pathway. Oncol Lett 2018, 15, 1861-1868, doi:10.3892/ol.2017.7520.

51. Domingo-Prim, J.; Bonath, F.; Visa, N. RNA at DNA Double-Strand Breaks: The Challenge of Dealing with DNA:RNA Hybrids. Bioessays 2020, 42, e1900225, doi:10.1002/bies.201900225.

52. Noordermeer, S.M.; Adam, S.; Setiaputra, D.; Barazas, M.; Pettitt, S.J.; Ling, A.K.; Olivieri, M.; Alvarez-Quilon, A.; Moatti, N.; Zimmermann, M., et al. The shieldin complex mediates 53BP1-dependent DNA repair. Nature 2018, 560, 117-121, doi:10.1038/s41586-018-0340-7. 


\section{Figures}
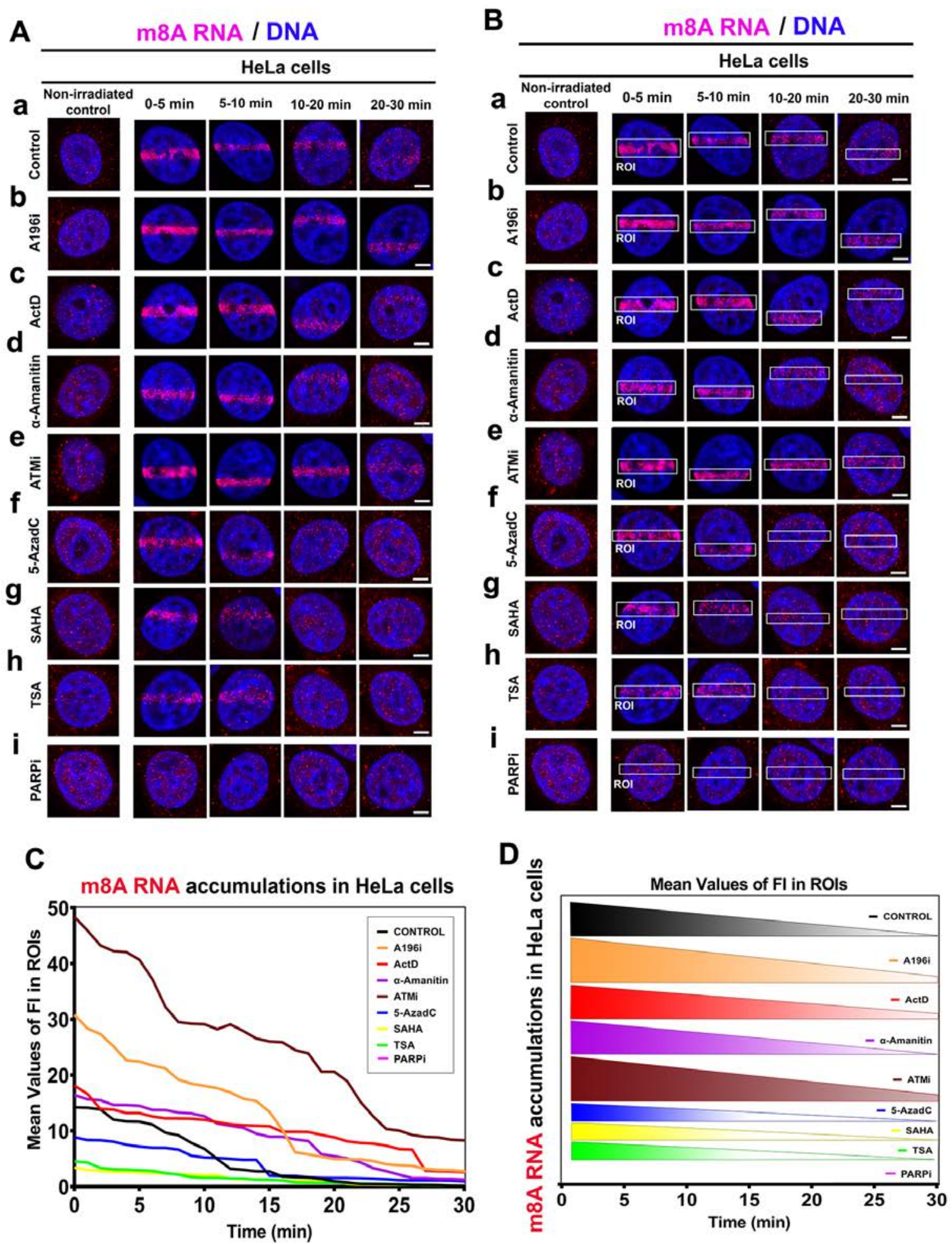

Figure 1. Recruitment of $\mathbf{m}^{8} \mathbf{A}$ RNA to locally irradiated chromatin. (A-B) $\mathrm{m}^{8} \mathrm{~A}$ RNA was studied at DNA lesions of (a) non-treated cells, (b) after the treatment of Suv20h1/2 inhibitor A196 (A196i) affectioning H4K20me2/me3, after inhibition of RNA polymerases I and II (c) 
Actinomycin D and (d) $\alpha$-amanitin). (e) We performed ATM depletion and (f) inhibition of DNA methyltransferase by 5-aza deoxycytidine. Inhibitors of histone deacetylases (HDACs) (g) suberoylanilide hydroxamic acid (Vorinostat; syn. SAHA), and (h) Trichostatin A (TSA) were studied. (i) PARP was inhibited by olaparib. Panel B shows frames with microirradiated regions of interest (ROI). Scale bars show $5 \mu \mathrm{m}$.
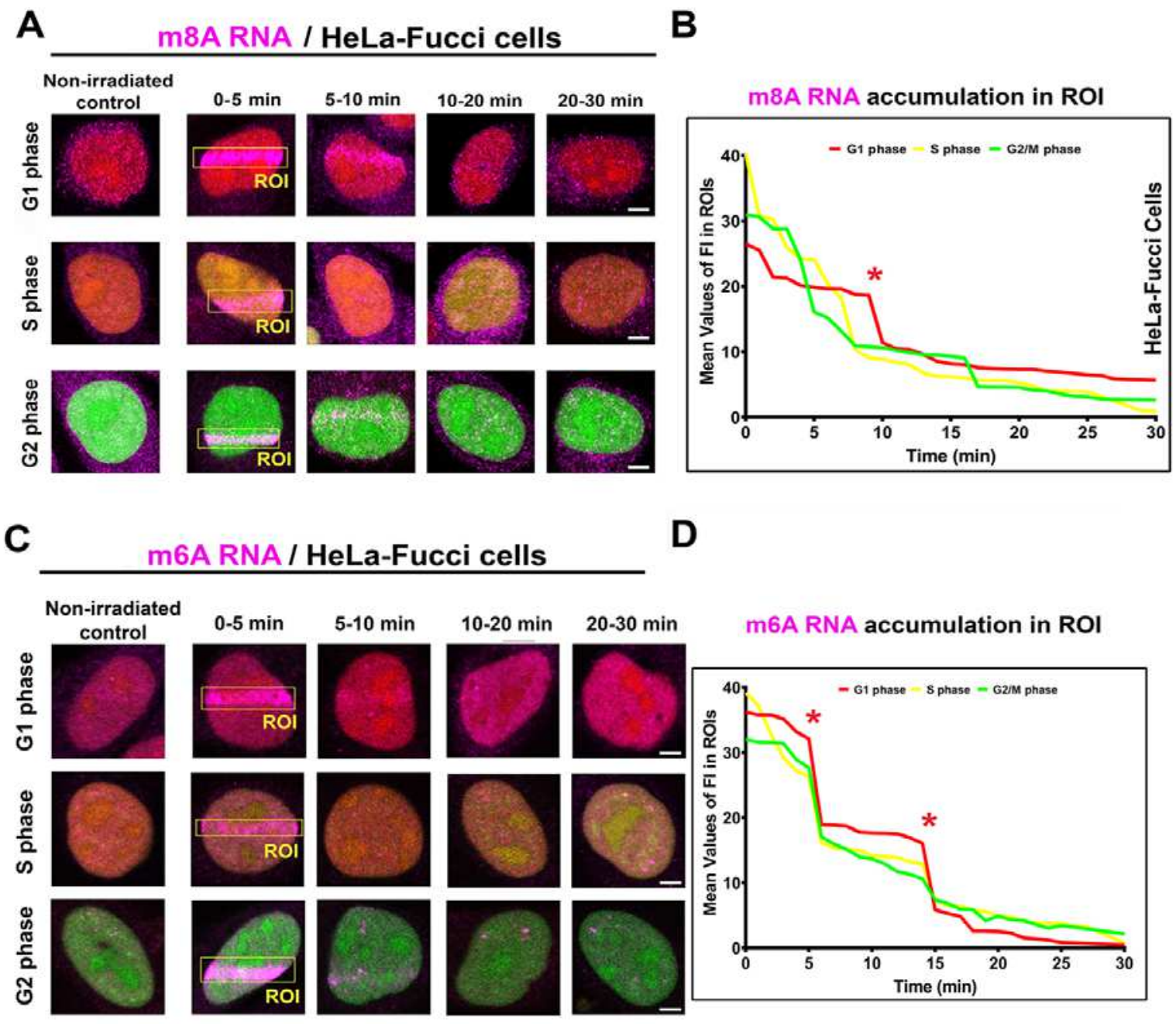

Figure 2. Accumulation of $m^{8} \mathrm{~A}$ RNAs and $\mathrm{m}^{6} \mathrm{~A}$ RNAs to DNA lesion during the whole interphase. Using FUCCI cellular system expressing RFP-tagged cdt1 in the G1 phase and GFPtagged geminin in the G2 phase of the cell cycle, we have observed an accumulation of both (A) $\mathrm{m}^{8} \mathrm{~A}$ RNA and (B) $\mathrm{m}^{6} \mathrm{~A}$ RNA to microirradiated chromatin in $\mathrm{G} 1, \mathrm{~S}$, and $\mathrm{G} 2$ phases of the cell cycle. Quantification of (C) $\mathrm{m}^{8} \mathrm{~A}$ RNA and (D) $\mathrm{m}^{6} \mathrm{~A}$ RNA fluorescence intensity in irradiated region of $\mathrm{G} 1, \mathrm{~S}, \mathrm{G} 2$ cells. 

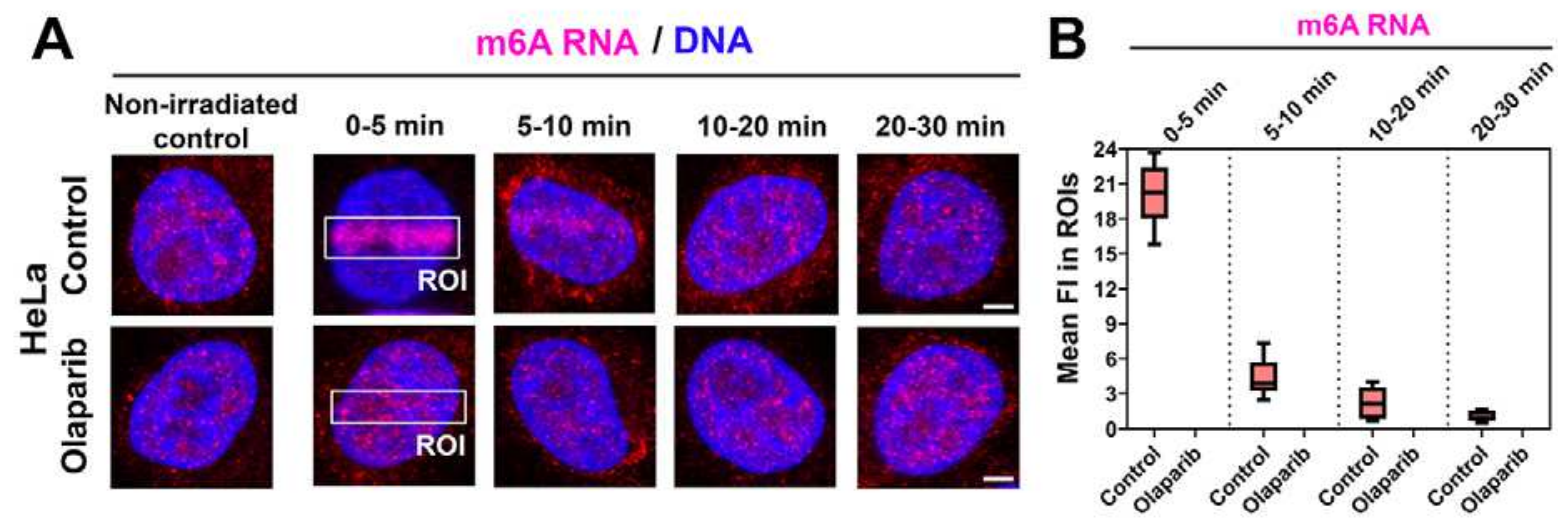

Figure 3. The level of $\mathbf{m}^{6} \mathbf{A}$ RNA in microirradiated regions. (A) $\mathrm{m}^{6} \mathrm{~A}$ RNA accumulated in microirradiated chromatin 0-5 min after laser exposure. (B) PARP inhibitor olaparib completely abrogated $\mathrm{m}^{6} \mathrm{~A}$ RNA recruitment to DNA lesions.

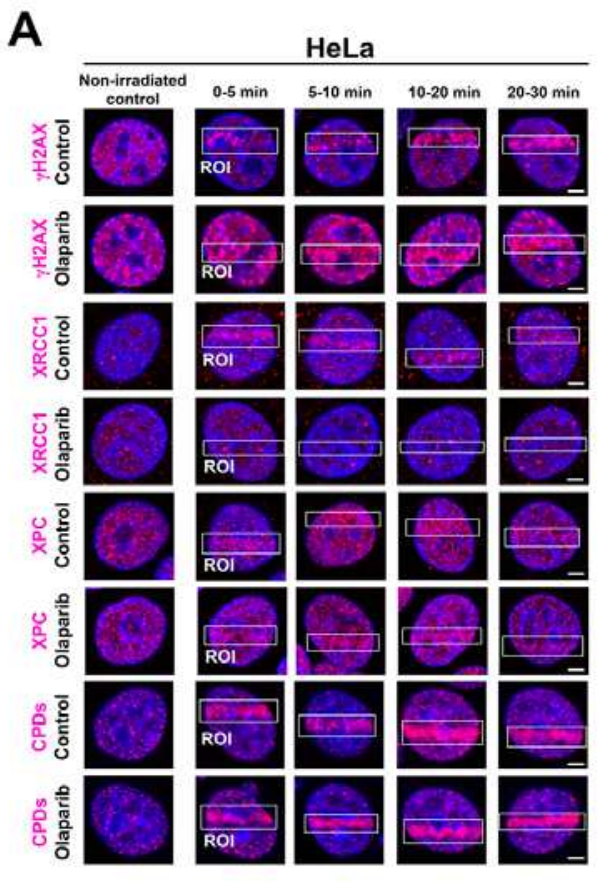

C

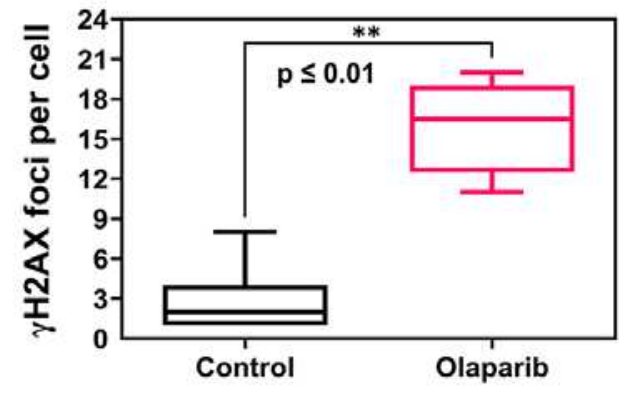

B
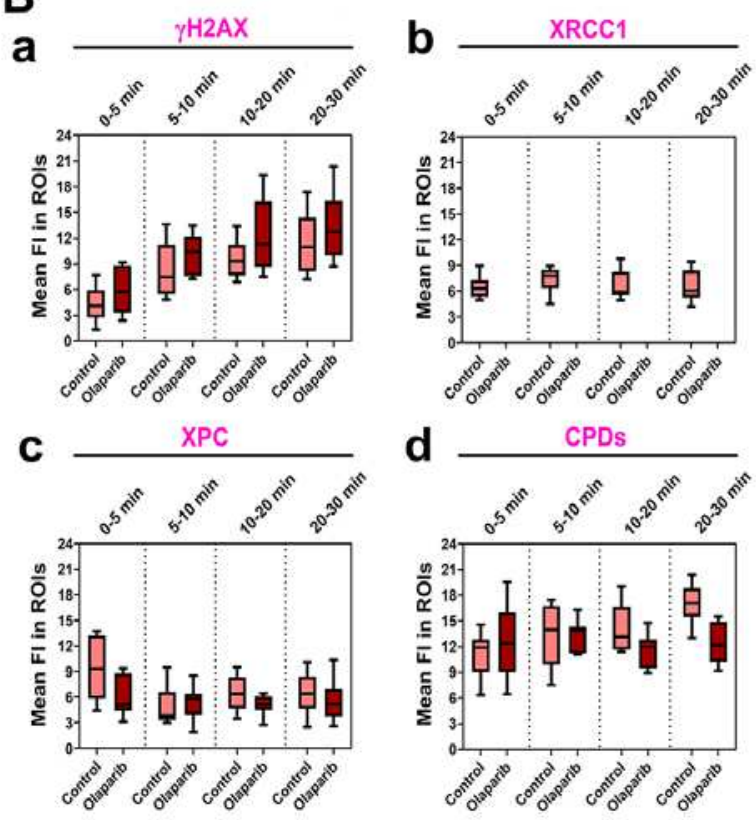

D

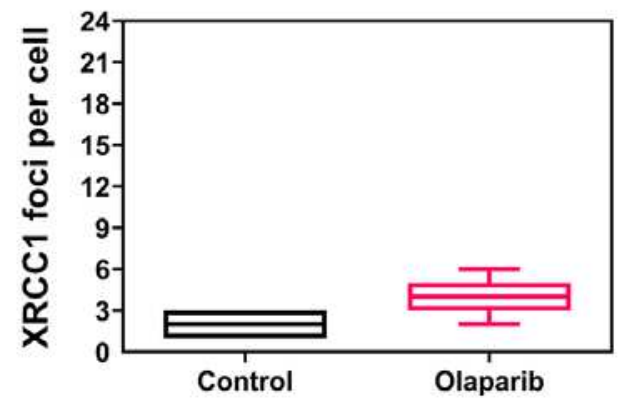

Figure 4. PARP inhibitor olaparib abolished XRCC1 recruitment to microirradiated chromatin. (A) PAPRi did not change the levels of XPC and CPDs at DNA lesions, while olaparib potentiates $\gamma \mathrm{H} 2 \mathrm{AX}$ positivity in the whole cell nuclei. PARPi prevents the recruitment 
of XRCC1 to UVA-damaged chromatin. Panel (B) shows fluorescence of (a) $\gamma \mathrm{H} 2 \mathrm{AX}$, (b) XRCC1, (c) XPC, (d) in microirradiated chromatin. (C) PARPi causes an increase of $\gamma \mathrm{H} 2 \mathrm{AX}$ positive foci per cell but does not change the number of XRCC1 positive foci.

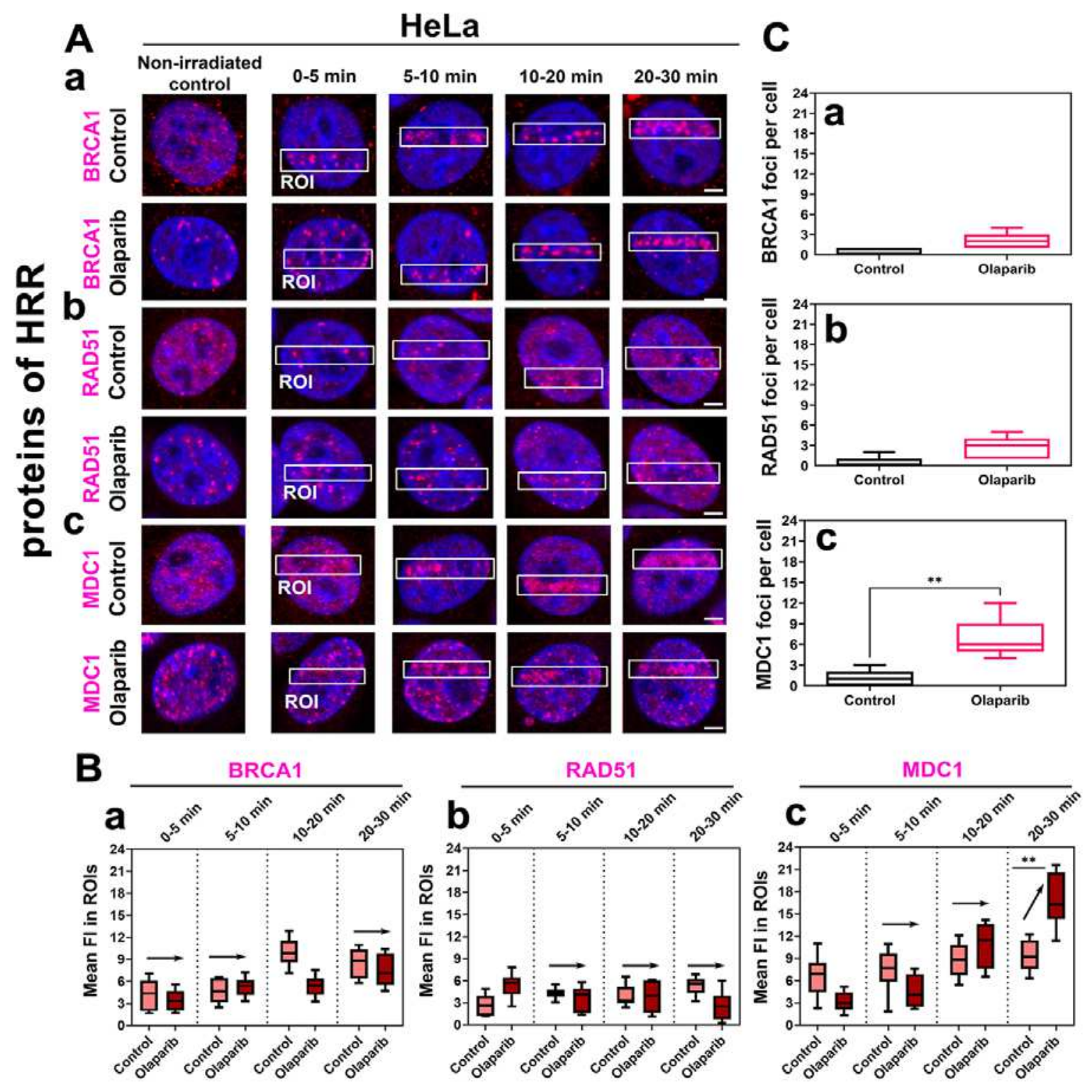

Figure 5. PARP inhibitor olaparib does not change the level of HRR-related proteins in microirradiated chromatin. (A, B) PAPRi did not alter the levels of (a) BRCA, (b) RAD51, (c) MDC1 in UVA-damaged chromatin. Only MDC1 was up-regulated in the later stages of DDR. (C) PARPi causes an increase of (c) MDC1 positive foci per cell. The number of (a) BRCA1 and (c) foci were not changed. 


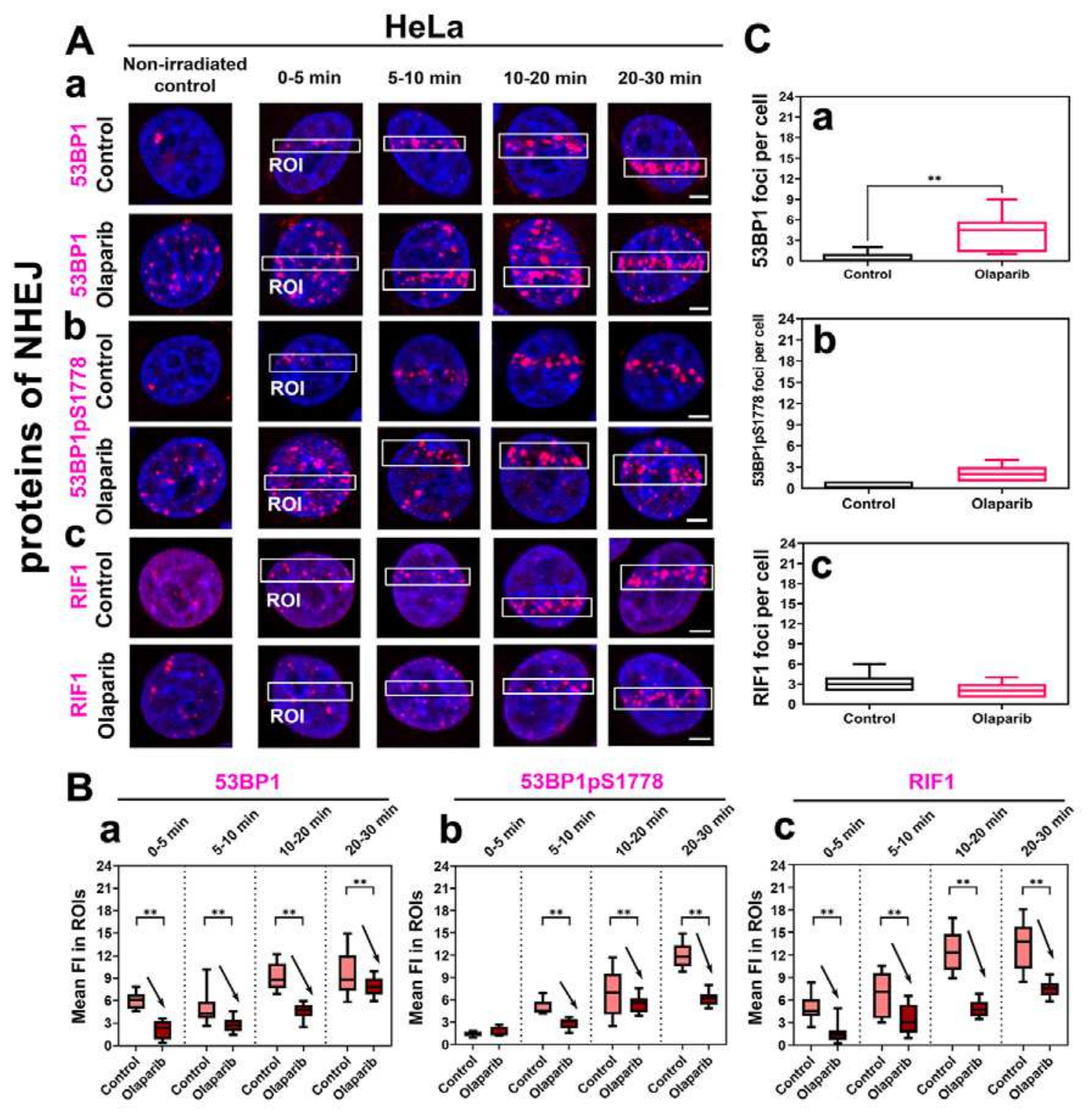

Figure 6. PARP inhibitor down-regulates NHEJ protein in microirradiated chromatin. (A, B) PAPRi decreased the levels of (a) 53BP1, (b) 53BP1pS1778, (c) RIF1 in UVA-damaged chromatin. Only MDC1 was up-regulated in the later stages of DDR. (C) PARPi did not change significantly the number of (a) 53BP1-, (b) 53BP1pS1778-, (c) RIF1-positive foci. 

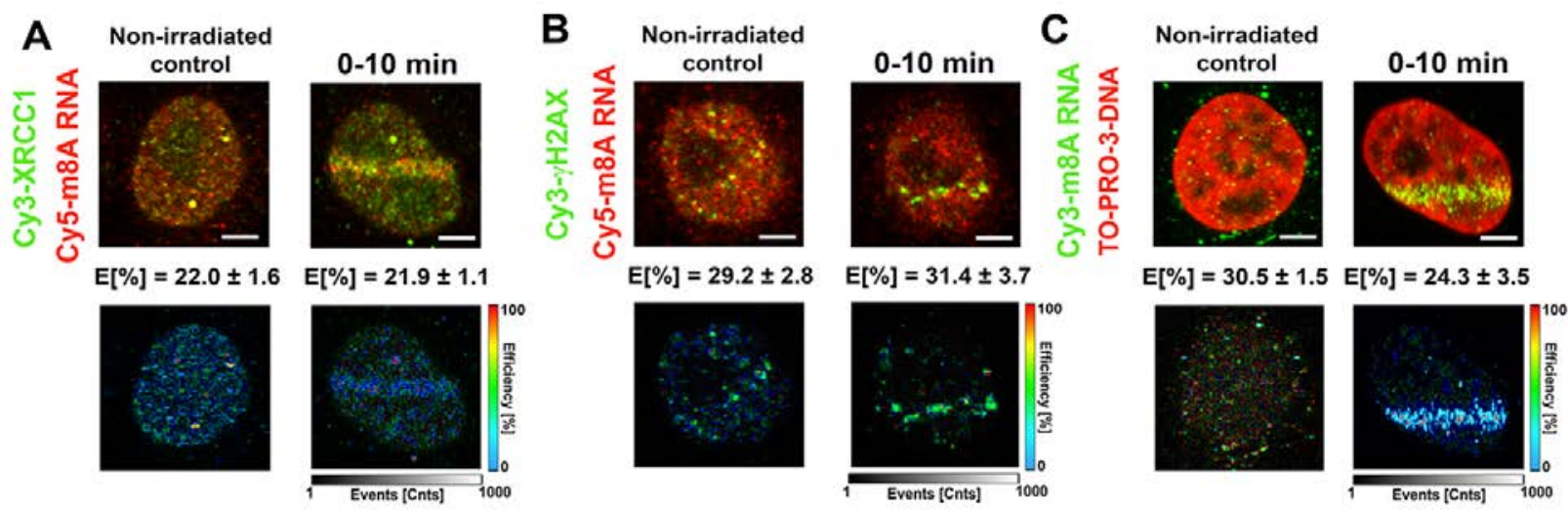

Figure 7. $\mathbf{m}^{8} \mathbf{A}$ RNA interacts with $\gamma \mathrm{H2AX}$ and DNA. FLIM-FRET analysis showed a weak interaction between (A) $\mathrm{m}^{8} \mathrm{~A}$ RNA and XRCC1, but a significant interaction between (B) $\mathrm{m}^{8} \mathrm{~A}$ RNA and $\gamma \mathrm{H} 2 \mathrm{AX}$ or $(\mathbf{C}) \mathrm{m}^{8} \mathrm{~A}$ RNA and DNA. 


\section{Figures}
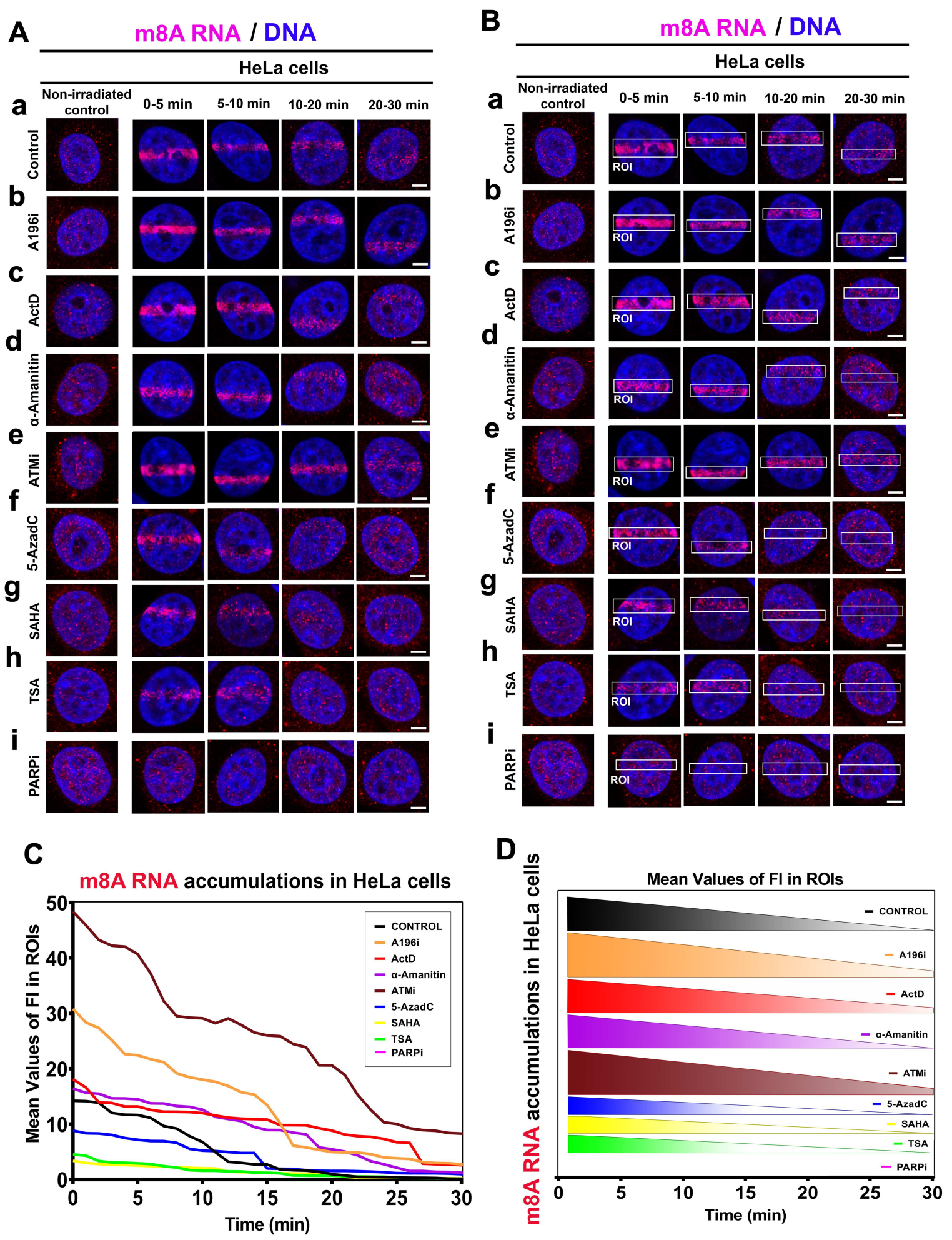

Figure 1

Recruitment of m8A RNA to locally irradiated chromatin. (A-B) m8A RNA was studied at DNA lesions of (a) non-treated cells, (b) after the treatment of Suv20h1/2 inhibitor A196 (A196i) affectioning H4K20me2/me3, after inhibition of RNA polymerases I and II (c) Actinomycin D and (d) a-amanitin). (e) 
We performed ATM depletion and (f) inhibition of DNA methyltransferase by 5-aza deoxycytidine. Inhibitors of histone deacetylases (HDACs) (g) suberoylanilide hydroxamic acid (Vorinostat; syn. SAHA), and (h) Trichostatin A (TSA) were studied. (i) PARP was inhibited by olaparib. Panel B shows frames with microirradiated regions of interest (ROI). Scale bars show $5 \mu \mathrm{m}$.

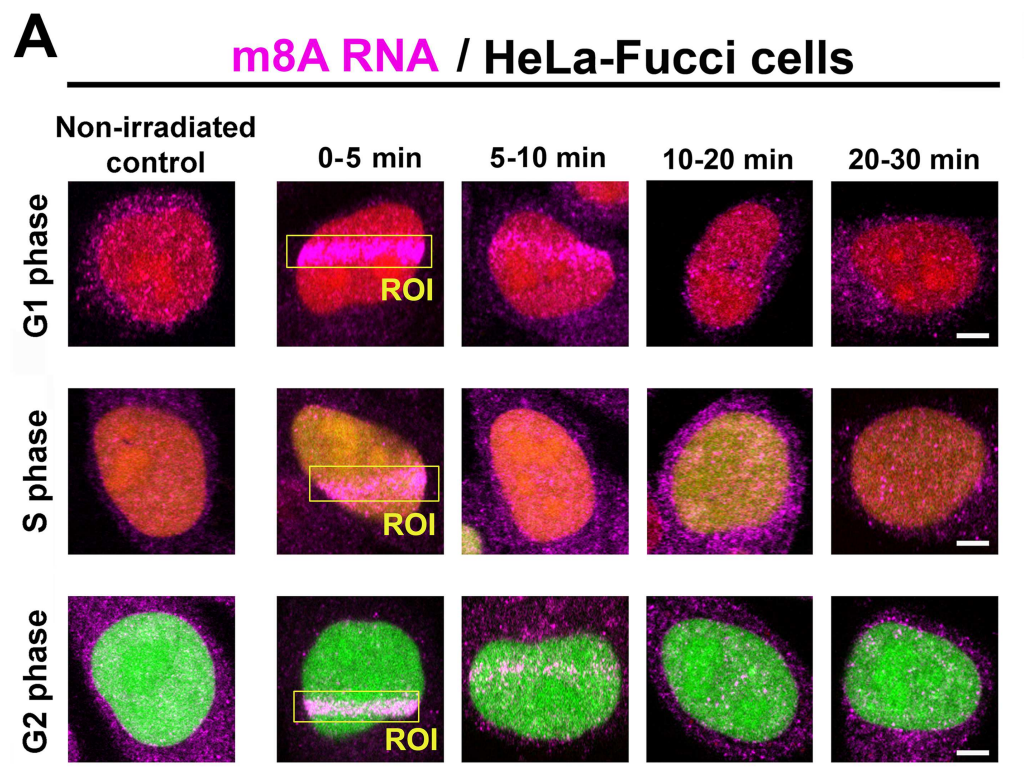

B

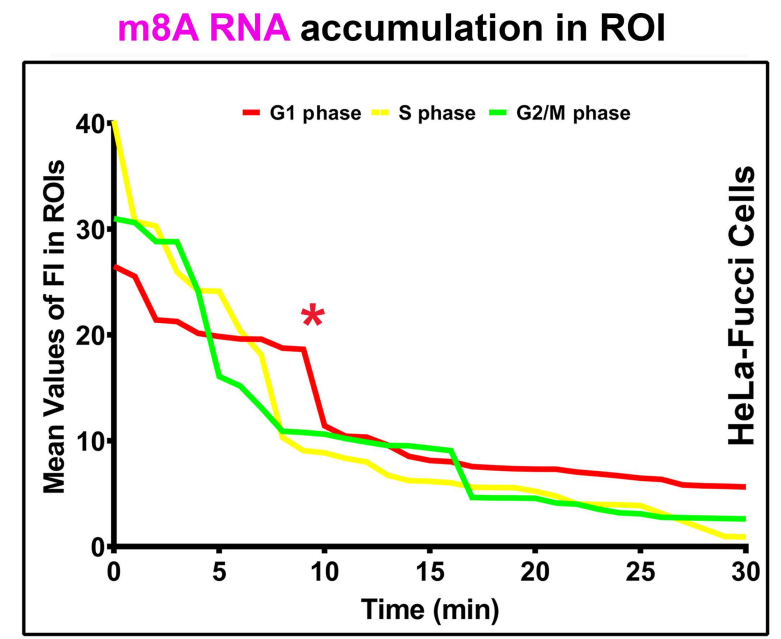

C m6A RNA / HeLa-Fucci cells
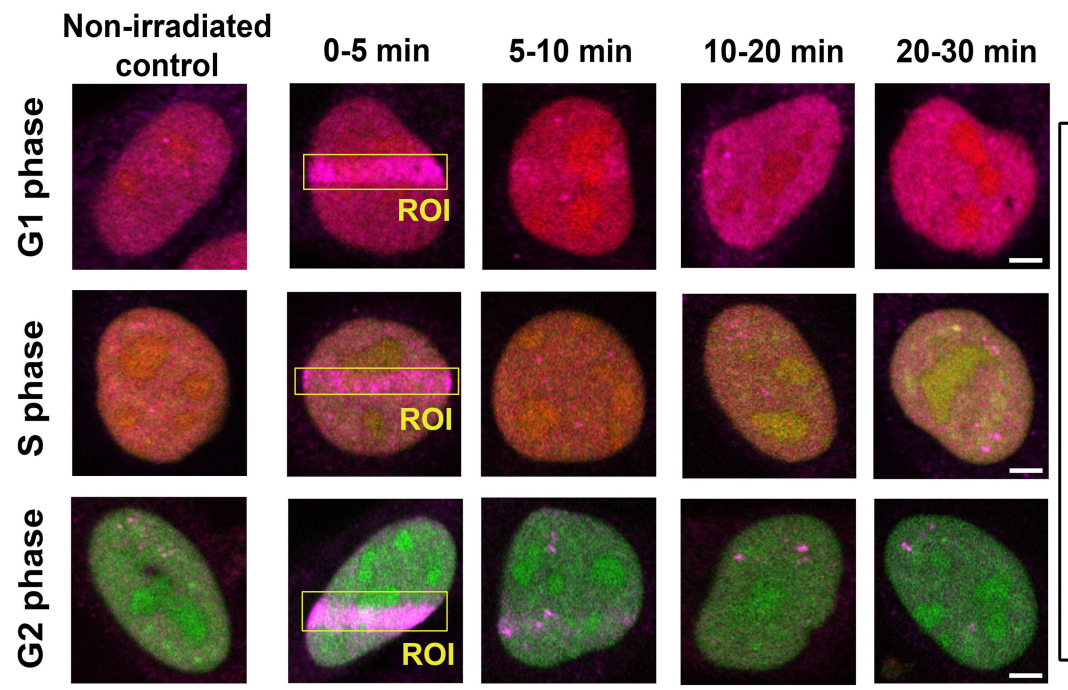

m6A RNA accumulation in ROI

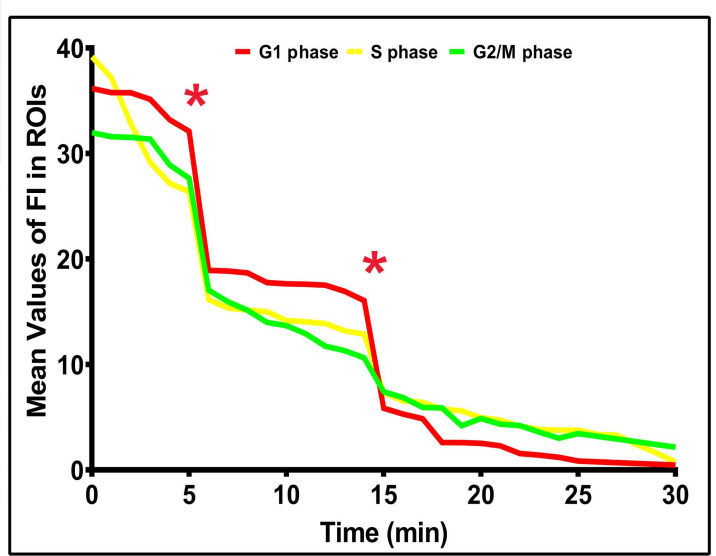

Figure 2

Accumulation of m8A RNAs and m6A RNAs to DNA lesion during the whole interphase. Using FUCCI cellular system expressing RFP-tagged cdt1 in the G1 phase and GFP-tagged geminin in the $\mathrm{G} 2$ phase of the cell cycle, we have observed an accumulation of both (A) m8A RNA and (B) m6A RNA to microirradiated chromatin in $\mathrm{G} 1, \mathrm{~S}$, and $\mathrm{G} 2$ phases of the cell cycle. Quantification of (C) M8A RNA and (D) m6A RNA fluorescence intensity in irradiated region of G1, S, G2 cells. 
A

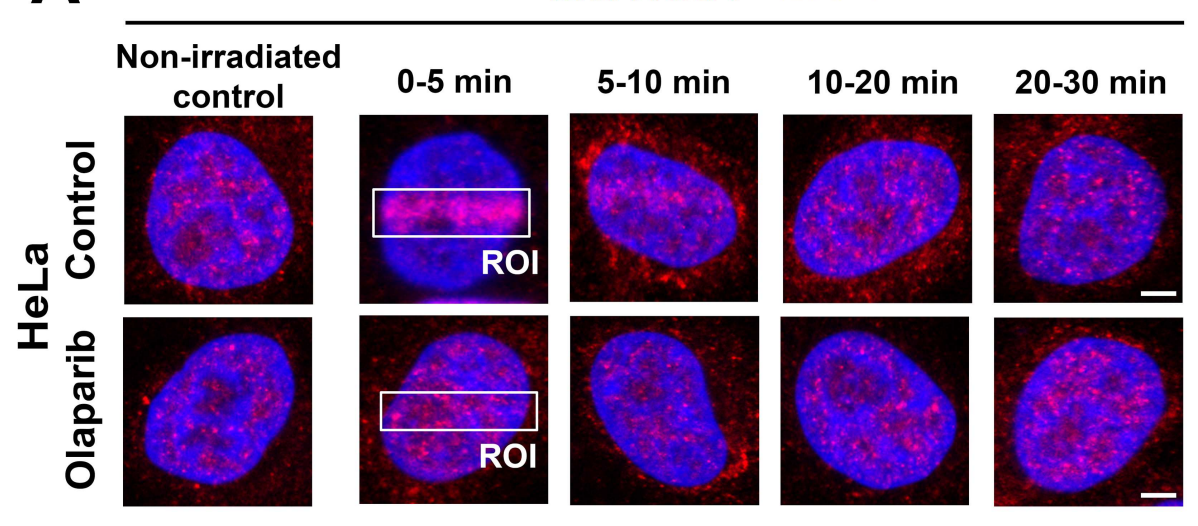

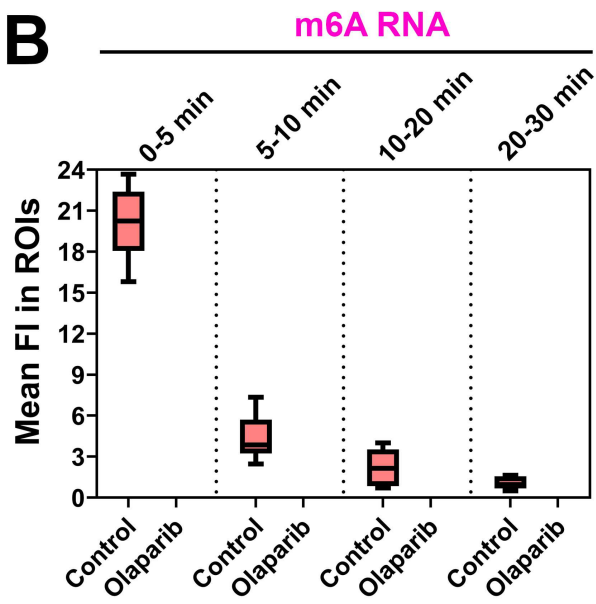

Figure 3

The level of m6A RNA in microirradiated regions. (A) m6A RNA accumulated in microirradiated chromatin 0-5 min after laser exposure. (B) PARP inhibitor olaparib completely abrogated m6A RNA recruitment to DNA lesions. 
A

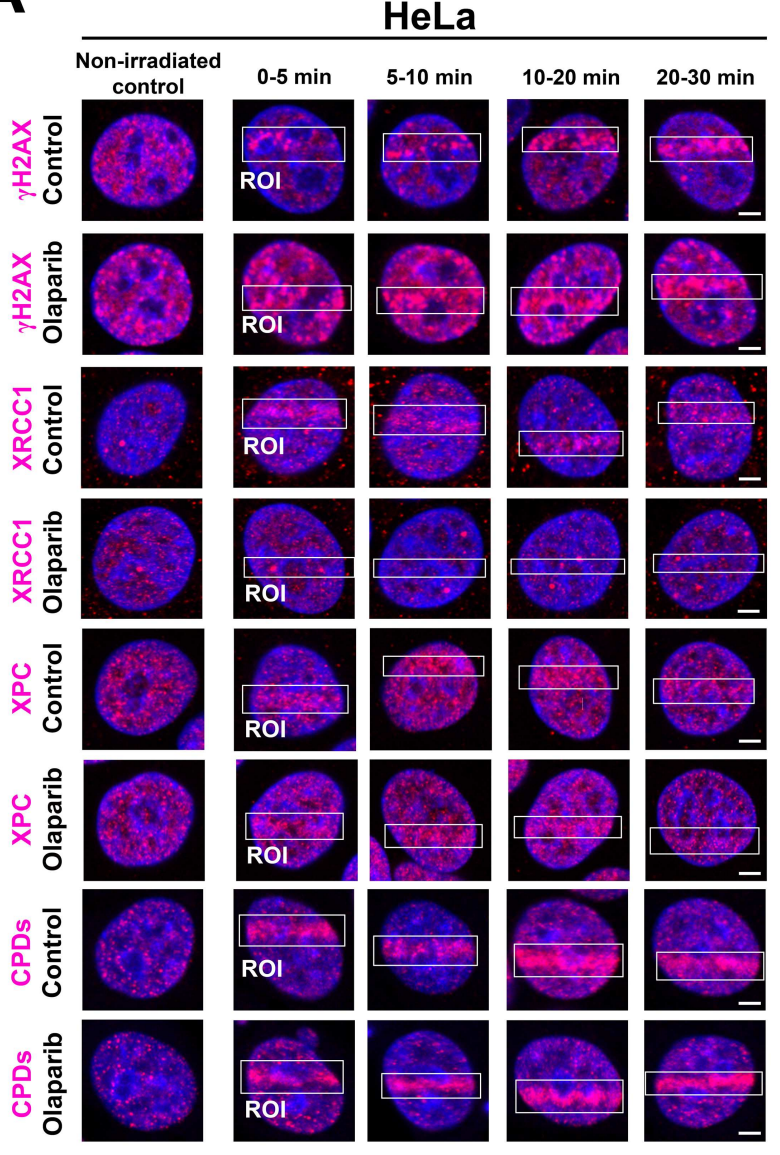

C

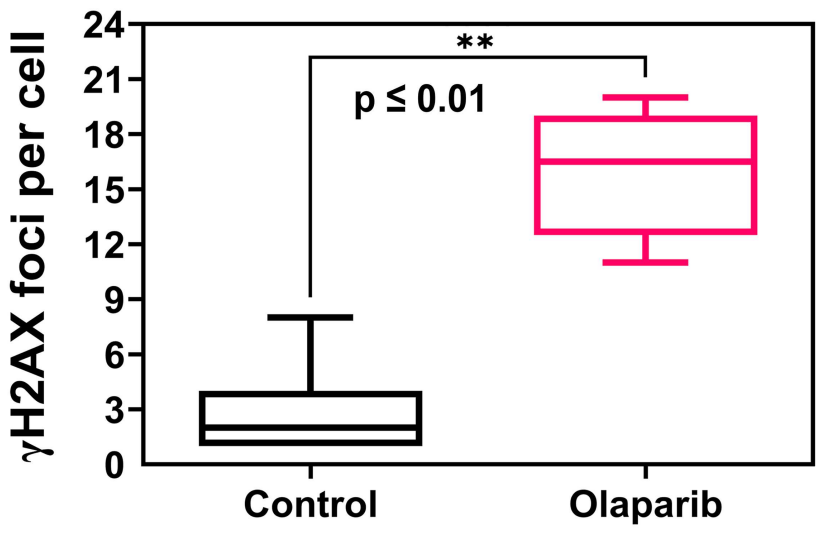

B
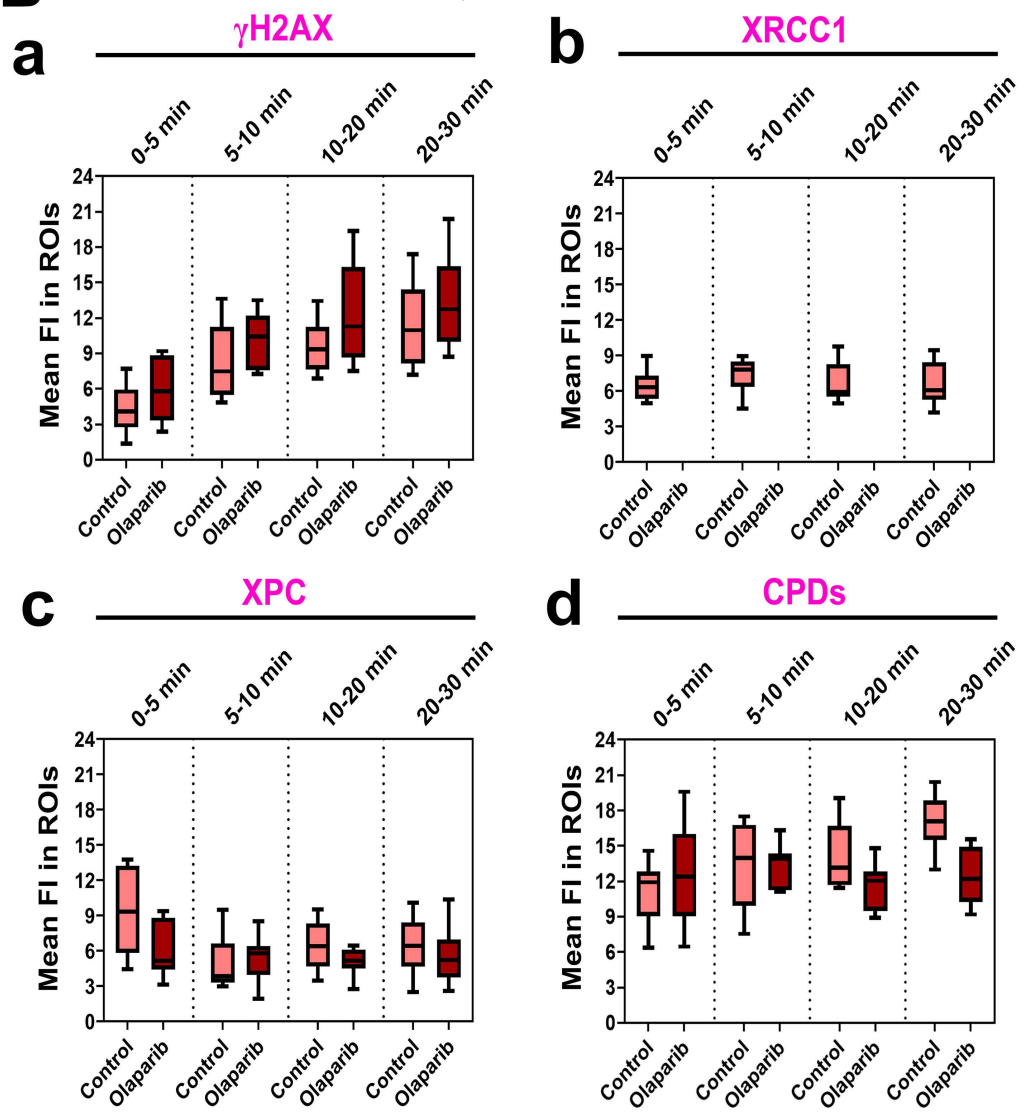

D

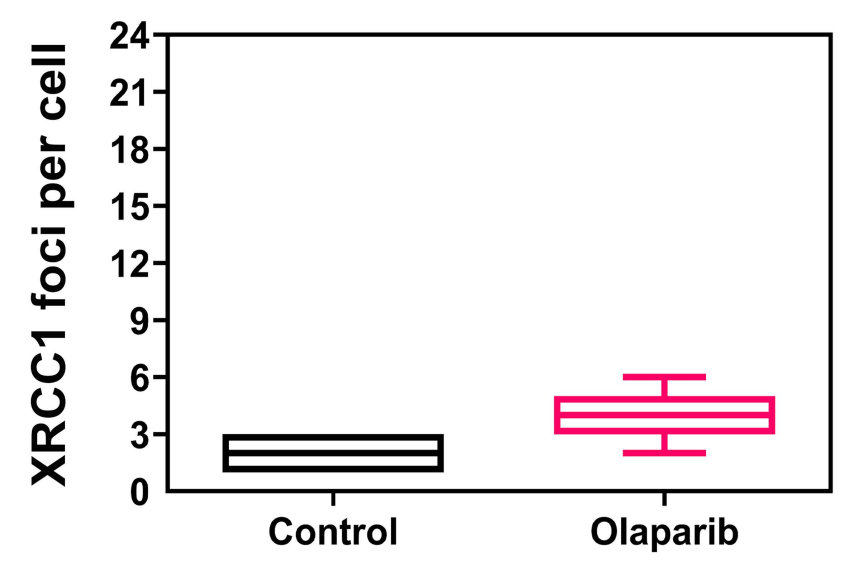

Figure 4

PARP inhibitor olaparib abolished XRCC1 recruitment to microirradiated chromatin. (A) PAPRi did not change the levels of XPC and CPDs at DNA lesions, while olaparib potentiates $\mathrm{YH} 2 \mathrm{AX}$ positivity in the whole cell nuclei. PARPi prevents the recruitment of XRCC1 to UVA-damaged chromatin. Panel (B) shows fluorescence of (a) YH2AX, (b) XRCC1, (c) XPC, (d) in microirradiated chromatin. (C) PARPi causes an increase of $\mathrm{YH} 2 \mathrm{AX}$ positive foci per cell but does not change the number of XRCC1 positive foci. 


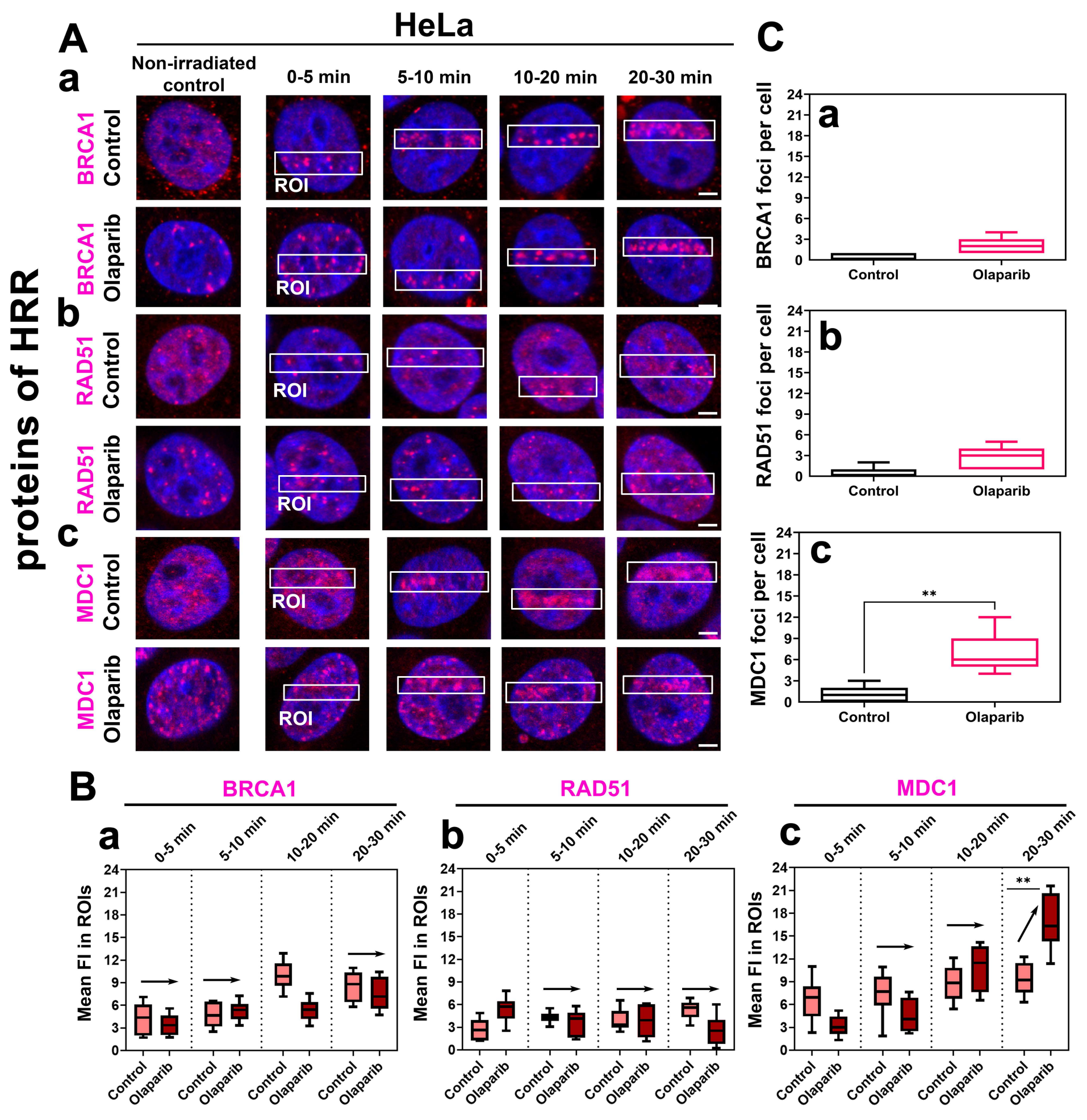

Figure 5

PARP inhibitor olaparib does not change the level of HRR-related proteins in microirradiated chromatin. (A, B) PAPRi did not alter the levels of (a) BRCA, (b) RAD51, (c) MDC1 in UVA-damaged chromatin. Only MDC1 was up-regulated in the later stages of DDR. (C) PARPi causes an increase of (c) MDC1 positive foci per cell. The number of (a) BRCA1 and (c) foci were not changed. 


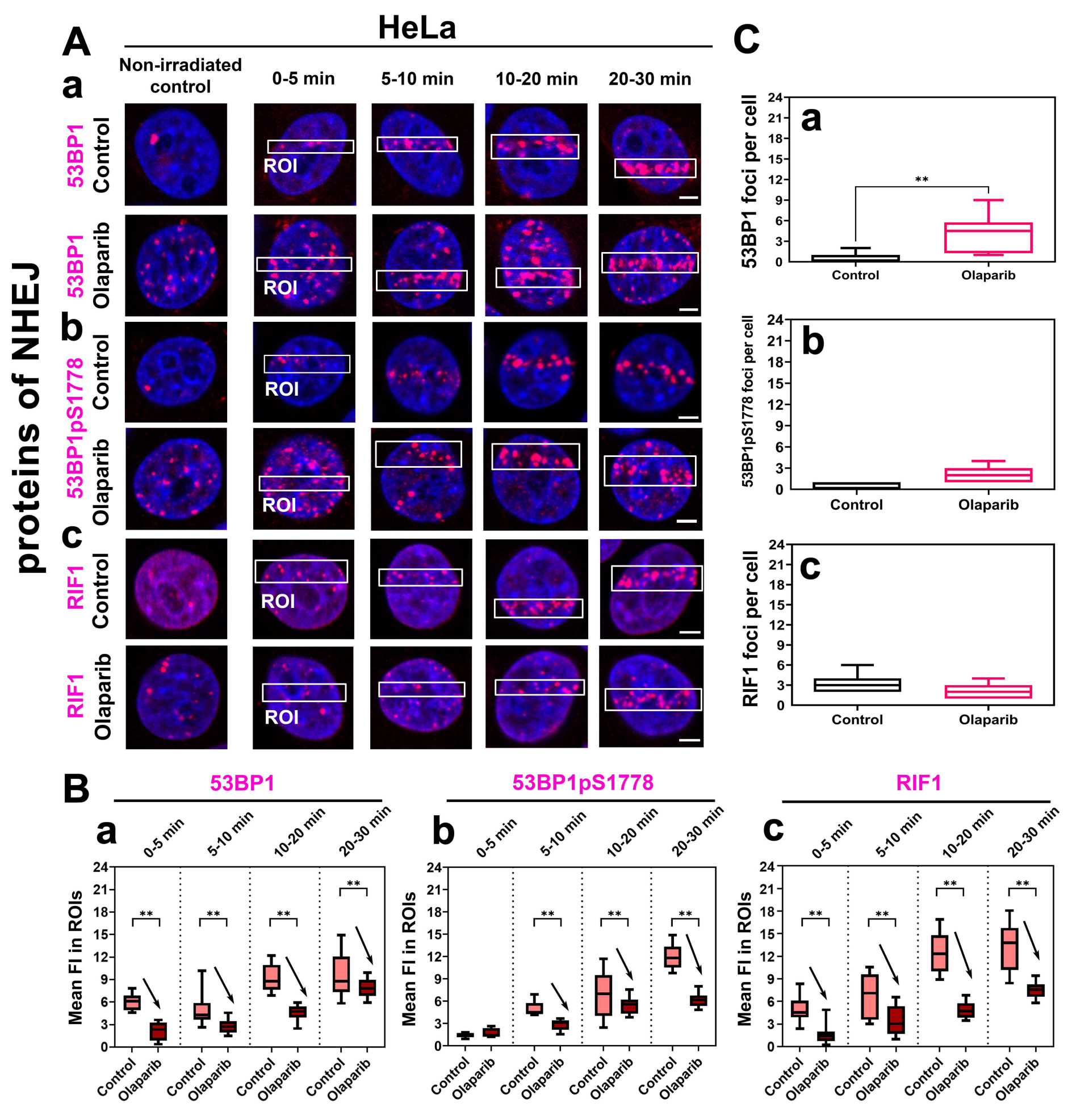

Figure 6

PARP inhibitor down-regulates NHEJ protein in microirradiated chromatin. (A, B) PAPRi decreased the levels of (a) 53BP1, (b) 53BP1pS1778, (c) RIF1 in UVA-damaged chromatin. Only MDC1 was up-regulated in the later stages of DDR. (C) PARPi did not change significantly the number of (a) 53BP1-, (b) 53BP1pS1778-, (c) RIF1-positive foci. 


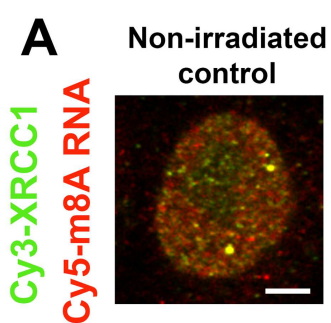

$E[\%]=22.0 \pm 1.6$

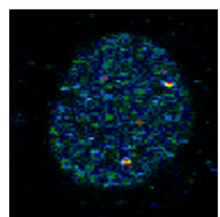

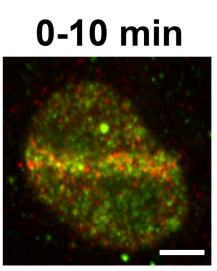

$E[\%]=21.9 \pm 1.1$

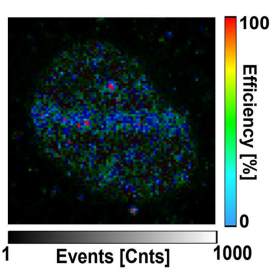

B Non-irradiated control

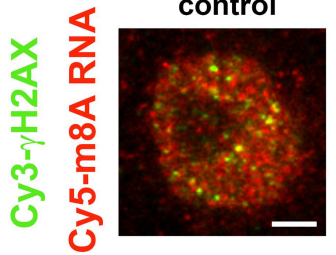

$E[\%]=29.2 \pm 2.8$

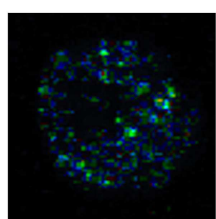

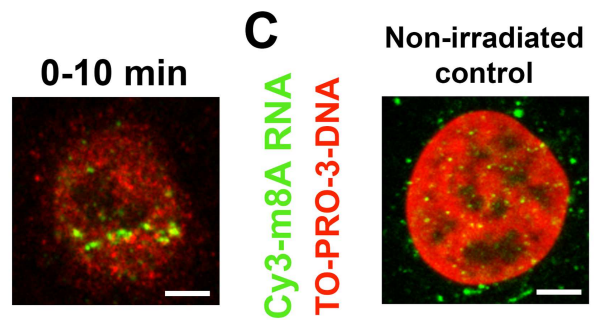

$E[\%]=31.4 \pm 3.7$

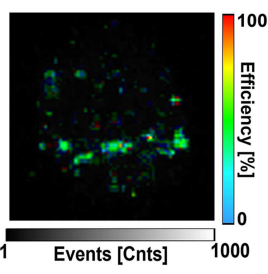

$0-10 \min$

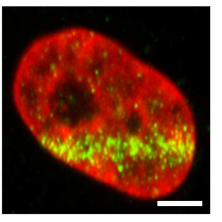

$E[\%]=30.5 \pm 1.5 \quad E[\%]=24.3 \pm 3.5$
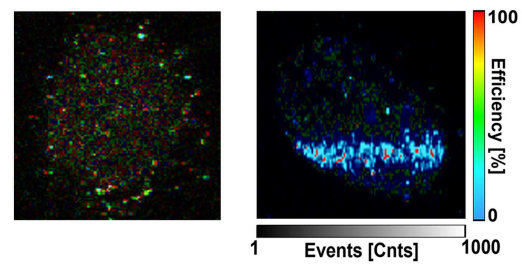

\section{Figure 7}

m8A RNA interacts with $\mathrm{YH} 2 \mathrm{AX}$ and DNA. FLIM-FRET analysis showed a weak interaction between (A) m8A RNA and XRCC1, but a significant interaction between (B) m8A RNA and $\gamma H 2 A X$ or (C) m8A RNA and DNA.

\section{Supplementary Files}

This is a list of supplementary files associated with this preprint. Click to download.

- GraphicalAbstract.tif 